\title{
Application of design of experiments (DoE) for optimised production of micro- and mesoporous Norway spruce bark activated carbons
}

\author{
Glaydson Simões dos Reis ${ }^{1} \cdot$ Sylvia H. Larsson ${ }^{1} \cdot$ Manon Mathieu $^{2} \cdot$ Mikael Thyrel $^{1} \cdot$ Tung Ngoc Pham $^{3,4}$
}

Received: 31 May 2021 / Revised: 27 August 2021 / Accepted: 31 August 2021

(c) The Author(s) 2021

\begin{abstract}
In this work, Norway spruce (Picea abies (Karst) L.) bark was employed as a precursor to prepare activated carbon using zinc chloride $\left(\mathrm{ZnCl}_{2}\right)$ as a chemical activator. The purpose of this study was to determine optimal activated carbon (AC) preparation variables by the response surface methodology using a Box-Behnken design (BBD) to obtain AC with high specific surface area $\left(\mathrm{S}_{\mathrm{BET}}\right)$, mesopore surface area $\left(\mathrm{S}_{\mathrm{MESO}}\right)$, and micropore surface area $\left(\mathrm{S}_{\mathrm{MICR}}\right)$. Variables and levels used in the design were pyrolysis temperature $\left(700,800\right.$, and $\left.900{ }^{\circ} \mathrm{C}\right)$, holding time $(1,2$, and $3 \mathrm{~h})$, and bark $/ \mathrm{ZnCl}_{2}$ impregnation ratio $\left(1,1.5\right.$, and 2). The optimal conditions for achieving the highest $\mathrm{S}_{\mathrm{BET}}$ were as follows: a pyrolysis temperature of $700{ }^{\circ} \mathrm{C}$, a holding time of $1 \mathrm{~h}$, and a spruce bark $/ \mathrm{ZnCl}_{2}$ ratio of 1.5 , which yielded an $\mathrm{S}_{\mathrm{BET}}$ value of $1374 \mathrm{~m}^{2} \mathrm{~g}^{-1}$. For maximised mesopore area, the optimal condition was at a pyrolysis temperature of $700{ }^{\circ} \mathrm{C}$, a holding time of $2 \mathrm{~h}$, and a bark $/ \mathrm{ZnCl}_{2}$ ratio of 2, which yielded a $\mathrm{S}_{\mathrm{MESO}}$ area of $1311 \mathrm{~m}^{2} \mathrm{~g}^{-1}$, where mesopores $\left(\mathrm{S}_{\mathrm{MESO} \%}\right)$ comprised $97.4 \%$ of total $\mathrm{S}_{\mathrm{BET}}$. Correspondingly, for micropore formation, the highest micropore area was found at a pyrolysis temperature of $800{ }^{\circ} \mathrm{C}$, a holding time of $3 \mathrm{~h}$, and a bark $/ \mathrm{ZnCl}_{2}$ ratio of 2 , corresponding to $1117 \mathrm{~m}^{2} \mathrm{~g}^{-1}$, with $94.3 \%$ of the total $\mathrm{S}_{\mathrm{BET}}$ consisting of micropores $\left(\mathrm{S}_{\mathrm{MICRO} \%}\right)$. The bark $/ \mathrm{ZnCl}_{2}$ ratio and pyrolysis temperature had the strongest impact on the $\mathrm{S}_{\mathrm{BET}}$, while the interaction between temperature and bark $/ \mathrm{ZnCl}_{2}$ ratio was the most significant factor for $\mathrm{S}_{\mathrm{MESO}}$. For the $\mathrm{S}_{\mathrm{MICRO}}$, holding time was the most important factor. In general, the spruce bark AC showed predominantly mesoporous structures. All activated carbons had high carbon and low ash contents. Chemical characterisation indicated that the ACs presented disordered carbon structures with oxygen functional groups on the ACs' surfaces. Well-developed porosity and a large surface area combined with favourable chemical composition render the activated carbons from Norway spruce bark with interesting physicochemical properties. The ACs were successfully tested to adsorb sodium diclofenac from aqueous solutions showing to be attractive products to use as adsorbents to tackle polluted waters.
\end{abstract}

Keywords Norway spruce bark $\cdot$ Picea abies $\cdot$ Design of experiments $\cdot$ DoE $\cdot$ Box-Behnken design $\cdot$ Mesoporous activated carbon $\cdot$ Sodium diclofenac adsorption

\section{Introduction}

Glaydson Simões dos Reis

glaydson.simoes.dos.reis@slu.se;

glaydsonambiental@gmail.com

1 Department of Forest Biomaterials and Technology, Biomass Technology Centre, Swedish University of Agricultural Sciences, 90183 Umeå, Sweden

2 IMT Mines Albi-Carmaux, Albi, France

3 Technical Chemistry, Department of Chemistry, Chemical-Biological Center, Umeå University, 90187 Umeå, Sweden

4 The University of Da-Nang, University of Science and Technology, Nguyen Luong Bang, 54, Da Nang, Vietnam
Activated carbon is a porous carbon material that has been subjected to reaction with gases and/or chemicals (e.g. $\mathrm{ZnCl}_{2}$ ) before, during, or after pyrolysis to obtain beneficial physicochemical and adsorptive properties [1]. Activated carbon (AC) can be produced with specific properties to meet the needs for low-cost and high-performance materials for more sustainable technologies [2-4]; it is one of the most common materials used as adsorbent [5-8] and catalyst and electrode material in environmental, chemical, and energy storage applications $[9,10]$.

To produce efficient ACs, a carbon source precursor (e.g. any biomass) is carbonised at temperatures above $500{ }^{\circ} \mathrm{C}$ in 
an inert atmosphere, in a process called pyrolysis [1, 8-10]. After pyrolysis, the fixed carbon is modified through chemical and/or physical activation [1, 8, 9]. Generally, pyrolysis and activation aim to generate $\mathrm{AC}$ with large specific surface area $\left(\mathrm{S}_{\mathrm{BET}}\right)$, pore volume, micropore area $\left(\mathrm{S}_{\mathrm{MICRO}}\right)$, and mesopore area $\left(\mathrm{S}_{\mathrm{MESO}}\right)$, and beneficial surface functionality-such as hydrophobicity and a large number of functional groups $[6,7,11]$. These properties depend on the manufacturing pyrolysis process $[9,10,12]$. The $\mathrm{AC}$ characteristics are severely influenced by several factors, such as (i) biomass precursor properties (chemical and structural), (ii) pyrolysis method (conventional, microwave-assisted, and/or hydrothermal), (iii) pyrolysis conditions (temperature, heating rate, and holding time), (iv) activation method (chemical and/or physical), and (v) activation conditions (carbon precursor/activator ratio, holding time, etc.) [8-12].

However, it is not trivial to elucidate how and to which extent these factors affect the AC production process and resulting characteristics $[11,13]$. Using the design of experiments (DoE) methodology enables identifying significant factors for specific processes and how they affect the resulting product properties $[11,13,14]$. DoE also provides resource efficiency by creating experimental spaces that maximise the output of relevant data from a minimum number of experiments for building empirical models that correlate responses with the experimental factors $[14,15]$.

DoE has been applied successfully to optimise the experimental conditions for AC preparation from precursors such as sewage sludge [11], coconut shell [16], bamboo [17], seed pods [18], jatropha hull [19], polycarbonate [20], and Turkish lignite [21]. Two factors were analysed when Karacan et al. [21] employed DoE to produce highly porous AC from lignite: chemical impregnation ratio (ranging from 0 to 4 ) and activation temperature (ranging from 500 to $900{ }^{\circ} \mathrm{C}$ ). The authors found that the optimum condition to prepare AC with the highest $\mathrm{S}_{\mathrm{BET}}$ was at a temperature of $800{ }^{\circ} \mathrm{C}$ with a chemical impregnation ratio of 2.05 . Ayyalusamy and Mishra [22] targeted the optimal conditions for the preparation of ACs from polyethylene terephthalate by evaluating the effect of three main factors (activation temperature, holding time, and chemical impregnation ratio) on two responses (high surface area and yield). Through DoE analysis, impregnation ratio and activation time were found to have the most significant effects on $\mathrm{S}_{\mathrm{BET}}$ values of the ACs. The optimised experimental response values were 537 $\mathrm{m}^{2} \mathrm{~g}^{-1}$ and $12.57 \%$ for $\mathrm{S}_{\mathrm{BET}}$ and AC yield, respectively, from optimal preparation conditions of $37.63 \%$ ratio of chemical activator, $600{ }^{\circ} \mathrm{C}$, and $30 \mathrm{~min}$.

In this work, Norway spruce (Picea abies (Karst.) L.) bark was used as a biomass precursor to produce activated carbons with highly developed porosities. Norway spruce covers large areas of Europe, accounting for more than 30 million ha [23], and has substantial economic importance for the wood market in Scandinavia and Europe. Yearly, only in Sweden, $90 \mathrm{Mm}^{3}$ standing volumes are harvested for industrial utilisation. Around $10-15 \%$ of this volume consists of bark that falls out as a low-value side-product at the sawmill and pulp industries. Spruce bark is rich in phenolic compounds, such as condensed tannins [24], and its main components comprise cellulose, hemicellulose, and lignin-making it very suitable as a precursor for AC [25].

In this work, Norway spruce bark ACs were produced by chemical activation using $\mathrm{ZnCl}_{2}$ as activator reagent. The literature reports that $\mathrm{ZnCl}_{2}$ acts as a superior activating agent compared to the others, producing AC with much higher developed porosity $[8,18]$. As a result, $\mathrm{ZnCl}_{2}$ provides ACs with high surface area and mass yield values [8]. In addition, $\mathrm{ZnCl}_{2}$ is well known for developing $\mathrm{AC}$ mesoporosity which is very suitable for solid-liquid separation [18]. The activation with $\mathrm{ZnCl}_{2}$ works as a standard method to make mesoporous $\mathrm{AC}$. In addition, the $\mathrm{ZnCl}_{2}$ has the advantage of using lower activation temperatures [8], making the AC preparation process cheaper when compared to other chemical activators, e.g. $\mathrm{KOH}$ and $\mathrm{H}_{3} \mathrm{PO}_{4}$. Combining all these factors can be extremely attractive to industry interests, making the process more economically feasible.

One potential drawback of using $\mathrm{ZnCl}_{2}$ is its potential toxicity if it is not managed correctly in the activation process; however, the acid leaching procedure that the pyrolysed materials are subjected using $6 \mathrm{M} \mathrm{HCl}$ at $80^{\circ} \mathrm{C}$ under reflux eliminates practically all $\mathrm{ZnCl}_{2}$ compounds from the carbon matrix $[5-8,18]$. This procedure eliminates the toxicity of the AC prepared with $\mathrm{ZnCl}_{2}[5-8,18]$.

To the best of our knowledge, only two studies with spruce bark as the main precursor for the preparation of AC have previously been reported $[12,26]$. Besides, no optimisation study for the production of ACs from spruce bark using DoE has been reported yet. Furthermore, the effects of pyrolysis temperature, holding time, and $\mathrm{ZnCl}_{2} /$ bark ratio on specific surface area $\left(\mathrm{S}_{\mathrm{BET}}\right)$, mesopore area $\left(\mathrm{S}_{\mathrm{MESO}}\right)$, and micropore area $\left(\mathrm{S}_{\mathrm{MICRO}}\right)$ were investigated and optimised using DoE. In addition, the resulting ACs were fully characterised by elemental analysis, X-ray photoelectron spectroscopy (XPS), Raman spectroscopy, hydrophobicity index, and surface morphologies (SEM). To evaluate a possible suitable and efficient application for the prepared ACs, they were tested to adsorb sodium diclofenac (DFC) from aqueous solutions.

\section{Materials and methods}

\subsection{Raw materials}

The spruce bark was delivered from a pulp and paper mill and prepared at the Biomass Technology Centre (BTC), 
Swedish University of Agricultural Sciences, Umeå, Sweden. The wet bark was dried in a custom-made plane drier at $40{ }^{\circ} \mathrm{C}$, shredded with a screen size of $15 \mathrm{~mm}$ (Lindner Micromat 2000, Lindner-Recyclingtech GmbH, Spittal an der Drau, Austria), hammer-milled with a screen size of 4 mm (Bühler DFZK 1, Bühler Group, Uzwil, Switzerland), representatively sampled according to ISO 18,135:2017, and cutting-milled with a screen size of $200 \mu \mathrm{m}$ using a Fritsch Pulverisette 14 mill equipment. The zinc chloride, $\mathrm{ZnCl}_{2}$, was acquired from Sigma-Aldrich, and tap water was used throughout the AC preparation.

\subsection{AC preparation}

The ACs were prepared through a one-step pyrolysis activation process according to a procedure previously reported in $[5-8,11]$. A total of $15.0 \mathrm{~g}$ of spruce bark was blended with the $\mathrm{ZnCl}_{2}$, and about $30.0 \mathrm{~mL}$ of water was added during mixing to form a homogeneous paste $[5-8,11]$. The paste was dried at $105{ }^{\circ} \mathrm{C}$ for $24 \mathrm{~h}$, was then put in a metallic crucible, and was heated with a fixed heating rate of $10{ }^{\circ} \mathrm{C} \mathrm{min}^{-1}$ under nitrogen flow of $600 \mathrm{~mL} \mathrm{~min}^{-1}$ in a conventional high-temperature oven. After the set temperature was reached, the sample was treated for a specific holding time. After treatment, the reactor was cooled under an $\mathrm{N}_{2}$ flow until the temperature reached $200{ }^{\circ} \mathrm{C}$ before the sample was taken out. To remove residual $\mathrm{ZnCl}_{2}$, samples were boiled for $2 \mathrm{~h}$ at $75{ }^{\circ} \mathrm{C}$ with a $6.0 \mathrm{M} \mathrm{HCl}$ solution under reflux conditions and washed with deionised water until the washing fluid obtained a stable $\mathrm{pH}$.

\subsection{Experimental design}

The spruce bark pyrolysis and activation were performed according to a Box-Behnken design (BBD). BBD is a factorial combination of a minimum of three factors with incomplete block designs. In each block, one factor is held at the central point $(0)$, while the others vary according to four different combination values for the upper $(+1)$ and lower $(-1)$ limits $[27,28]$. Our experimental design comprised 15 experiments which included 12 factorial points and three centre points for the factors pyrolysis temperature $\left({ }^{\circ} \mathrm{C}\right)$, pyrolysis holding time $(\mathrm{h})$, and $\mathrm{ZnCl}_{2}$ /bark dry matter mass ratio (-), as listed in Table 1. Based on the literature and preliminary experiments, these three factors and their ranges were chosen [11, 13-17]. The running order of the experiments was randomised to minimise the effects of the uncontrolled factors.

The studied responses were mass yield (\%); BET surface area, $\mathrm{S}_{\mathrm{BET}}\left(\mathrm{m}^{2} \mathrm{~g}^{-1}\right)$; mesopore surface area, $\mathrm{S}_{\mathrm{MESO}}\left(\mathrm{m}^{2} \mathrm{~g}^{-1}\right)$; micropore surface area, $\mathrm{S}_{\mathrm{MICRO}}\left(\mathrm{m}^{2} \mathrm{~g}^{-1}\right)$; and pore volume $\left(\mathrm{cm}^{2} \mathrm{~g}^{-1}\right)$.

Minitab software (version 20, Minitab Inc., USA) was used for the BBD analysis to elucidate factor influences on the responses $\left(\mathrm{S}_{\mathrm{BET}}, \mathrm{S}_{\mathrm{MESO}}\right.$, and $\left.\mathrm{S}_{\mathrm{MICRO}}\right)$ and generate factor values for optimal responses.

\subsection{AC characterisation}

The mass yield (\%) was calculated from the dry matter quota after and before activation.

Table 1 Experimental Box-Behnken design (BBD) matrix

\begin{tabular}{|c|c|c|c|c|c|c|}
\hline Sample name & Temperature & Holding time & $\begin{array}{l}\mathrm{ZnCl}_{2} / \text { bark } \\
\text { mass ratio }\end{array}$ & Temperature $\left({ }^{\circ} \mathrm{C}\right)$ & $\begin{array}{l}\text { Holding time } \\
\text { (h) }\end{array}$ & $\begin{array}{l}\mathrm{ZnCl}_{2} / \text { bark } \\
\text { mass ratio } \\
(-)\end{array}$ \\
\hline & Coded factor levels & & & Uncoded factor levels & & \\
\hline $\mathrm{AC} 1$ & 1 & -1 & 0 & 900 & 1 & 1.5 \\
\hline $\mathrm{AC} 2$ & 1 & 0 & 1 & 900 & 2 & 2 \\
\hline $\mathrm{AC} 3$ & 0 & 0 & 0 & 800 & 2 & 1.5 \\
\hline $\mathrm{AC} 4$ & -1 & 1 & 0 & 700 & 3 & 1.5 \\
\hline AC5 & 0 & 0 & 0 & 800 & 2 & 1.5 \\
\hline AC6 & -1 & 0 & 1 & 700 & 2 & 2 \\
\hline $\mathrm{AC7}$ & 0 & 0 & 0 & 800 & 2 & 1.5 \\
\hline $\mathrm{AC} 8$ & 0 & 1 & 1 & 800 & 3 & 2 \\
\hline AC9 & 0 & 1 & -1 & 800 & 3 & 1 \\
\hline AC10 & 1 & 0 & -1 & 900 & 2 & 1 \\
\hline $\mathrm{AC} 11$ & -1 & 0 & -1 & 700 & 2 & 1 \\
\hline $\mathrm{AC} 12$ & 0 & -1 & 1 & 800 & 1 & 2 \\
\hline AC13 & 0 & -1 & -1 & 800 & 1 & 1 \\
\hline AC14 & -1 & -1 & 0 & 700 & 1 & 1.5 \\
\hline AC15 & 1 & 1 & 0 & 900 & 3 & 1.5 \\
\hline
\end{tabular}


Analyses of surface areas $\left(\mathrm{S}_{\mathrm{BET}}, \mathrm{S}_{\mathrm{MESO}}\right.$, and $\left.\mathrm{S}_{\mathrm{MICRO}}\right)$ and pore volume were carried out by $\mathrm{N}_{2}$ sorption/desorption analysis (Tri Star 3000 apparatus, Micrometrics Instrument Corp.). Before the analysis, samples were degassed at $180{ }^{\circ} \mathrm{C}$ for $3 \mathrm{~h}$ in an $\mathrm{N}_{2}$ atmosphere. The surface areas, pore size distribution, and pore volume were calculated by multipoint nitrogen gas sorptiometry according to the Brunauer-Emmett-Teller (BET) principle. BET and $t$-plot equations were used to calculate the $\mathrm{S}_{\mathrm{BET}}, \mathrm{S}_{\mathrm{MESO}}$, and $\mathrm{S}_{\mathrm{MICRO}}$

The elemental analysis was performed using an elemental analyser (EA-IsoLink, Thermo Fisher Scientific). Shortly, $0.05 \mathrm{~g}$ oven-dried samples were used to determine total carbon $(\mathrm{C})$, nitrogen $(\mathrm{N})$, oxygen $(\mathrm{O})$, and hydrogen $(\mathrm{H})$ contents. The ash mass fraction was determined by subtracting the $\mathrm{C}, \mathrm{N}, \mathrm{O}$, and $\mathrm{H}$ mass fractions from the total mass of the sample.

XPS spectra were collected using a Kratos Axis Ultra DLD electron spectrometer using a monochromated Al $\mathrm{K}_{\alpha}$ source operated at $150 \mathrm{~W}$. An analyser pass energy of $160 \mathrm{eV}$ for acquiring survey spectra and a pass energy of $20 \mathrm{eV}$ for individual photoelectron lines were used. The samples were gently hand-pressed using a clean Ni spatula into the powder sample holder. Because activated carbon is conductive, no charge neutralisation system was used. The binding energy (BE) scale was calibrated following the ASTM E2108 and ISO 15,472 standards. Processing of the spectra was accomplished with the Kratos software.

Raman spectra were collected using a Bruker Bravo spectrometer (Bruker, Ettlingen, Germany) attached to a docking measuring station. Shortly, $0.5 \mathrm{~g}$ of AC samples were manually ground using an agate mortar and pestle, placed in $2.5-\mathrm{mL}$ glass vials, and scanned in the $300-3200 \mathrm{~cm}^{-1}$ spectral range at $4 \mathrm{~cm}^{-1}$ resolution for 256 scans. Min-Max normalisation over the $1000-2000 \mathrm{~cm}^{-1}$ region and smoothing ( 9 points) was done using the built-in functions of the OPUS software (version 7, Bruker Optik GmbH, Ettlingen, Germany). No baseline correction was needed.

The $\mathrm{H}_{2} \mathrm{O}$ vapour adsorption isotherms were determined by dynamic vapour sorption (DVS Advantage, Surface Measurement Systems). Shortly, $0.02 \mathrm{~g}$ was used to get the isotherms. Equilibrium moisture contents (EMCs) were collected by recording the sample weight at each $1 \% \mathrm{RH}$ in the $0-10 \%$ range, each $2.5 \% \mathrm{RH}$ in the $10-20 \%$ range, each $5 \%$ in the $20-50 \%$ range, and each $10 \%$ in the $50-95 \%$ range during adsorption, and at each $20 \%$ during desorption.

The hydrophobicity/hydrophilicity index (HI) was calculated according to a method previously reported in the literature [22]: $0.3 \mathrm{~g}$ of each $\mathrm{AC}$ was placed into $5-\mathrm{mL}$ beakers and inserted into plugged 1.5-L E-flasks with saturated atmosphere solvent vapour (water or n-heptane) using $80 \mathrm{~mL}$ of each solvent. The beakers were placed in the centre of the E-flasks to avoid contact with the flask walls. After $24 \mathrm{~h}$, the beakers were removed and weighed. The weight gained was used to calculate the maximum $\mathrm{H}_{2} \mathrm{O}$ vapour adsorption.

\subsection{Diclofenac (DCF) batch adsorption tests}

The DCF solution used for the adsorption tests was at an initial concentration of $2000 \mathrm{mg} \mathrm{L}^{-1}$ and a $\mathrm{pH}$ of 6.0. Aliquots of $20.00 \mathrm{~mL}$ of DFC were added to 50.0-mL Falcon flat tubes containing $30 \mathrm{mg}$ of each AC. The Falcon tubes containing DCF and ACs were agitated in a shaker model TE-240 for $4 \mathrm{~h}$. Afterwards, to separate the DFC and ACs, the flasks were centrifuged. After adsorption, the residual solution of DCF was quantified using a UV-Visible spectrophotometer (Shimadzu 1800) at a maximum wavelength of $285 \mathrm{~nm}$. The amount of DCF adsorbed by the ACs was calculated using Eq. (1):

$q=\frac{\left(C_{o}-C_{f}\right)}{m} \cdot V$

\section{Results and discussion}

\subsection{Yield and textural characteristics of the ACs}

Table 2 shows $\mathrm{S}_{\mathrm{BET}}, \mathrm{S}_{\mathrm{MESO}}, \mathrm{S}_{\mathrm{MICRO}}, \mathrm{S}_{\mathrm{MESO} \%}, \mathrm{~S}_{\mathrm{MICRO} \%}$, pore volume, and mass yield of the prepared ACs. The mass yield of the produced ACs ranged from 30.3 to $41 \%$. The lowest yield was obtained for $\mathrm{AC} 15\left(900{ }^{\circ} \mathrm{C}, 3 \mathrm{~h}\right.$, and $\mathrm{ZnCl}_{2} / \mathrm{bark}$ ratio 1.5), and the highest for $\mathrm{AC} 6\left(700{ }^{\circ} \mathrm{C}, 2 \mathrm{~h}\right.$, and $\mathrm{ZnCl}_{2} /$ bark ratio 2). It has previously been reported that a higher pyrolysis temperature and longer holding time reduce the mass yield $[29,30]$ due to more volatile compounds exiting the biomass during the pyrolysis.

For instance, Bergna et al. [29] produced ACs from birch and spruce wood chips at two different activation holding times: 2 and $4 \mathrm{~h}$, with reported mass yield values of $10.4 \%$ and $5.5 \%$ for birch and $15.2 \%$ and $11.5 \%$ for spruce, respectively. Sulaiman et al. [30] pyrolysed cassava stem to produce AC with yields varying from 3.8 to $25.7 \%$. In another work [31], ACs were prepared by using $\mathrm{CO}_{2}$ and $\mathrm{MgCl}_{2}$ as activation agents. The yield of the $\mathrm{AC}$ prepared with $\mathrm{CO}_{2}$ was $6.54 \%$, while $\mathrm{MgCl}_{2}$ activation resulted in a yield of $18.1 \%$. The abovementioned studies presented a substantially lower yield compared to the ACs prepared in this work. Generally, $\mathrm{ZnCl}_{2}$ activation gives higher yields than activation with other chemical reagents [29, 30]. Impregnation with $\mathrm{ZnCl}_{2}$ results in degradation of the cellulosic material, and carbonisation produces dehydration that results in charring and aromatisation of the carbon skeleton, thereby avoiding huge losses $[6,8]$. 
Table 2 Textural properties and mass yield of the ACs

\begin{tabular}{|c|c|c|c|c|c|c|c|c|}
\hline Sample name & $\begin{array}{l}\text { Experimen- } \\
\text { tal conditions } \\
\left({ }^{\circ} \mathrm{C}: \text { h:ratio }\right)\end{array}$ & $\mathrm{S}_{\mathrm{BET}}\left(\mathrm{m}^{2} \mathrm{~g}^{-1}\right)$ & $\mathrm{S}_{\mathrm{MESO}}\left(\mathrm{m}^{2} \mathrm{~g}^{-1}\right)$ & $\mathrm{S}_{\text {MICRO }}\left(\mathrm{m}^{2} \mathrm{~g}^{-1}\right)$ & $\mathrm{S}_{\mathrm{MESO} \%}(\%)$ & $\mathrm{S}_{\mathrm{MICRO} \%}(\%)$ & $\begin{array}{l}\text { Pore vol- } \\
\text { ume }\left(\mathrm{cm}^{3}\right. \\
\left.\mathrm{g}^{-1}\right)\end{array}$ & Mass yield (\%) \\
\hline $\mathrm{AC} 1$ & $900: 1: 1.5$ & 1019 & 837 & 182 & 82.1 & 17.9 & 0.57 & 37.5 \\
\hline $\mathrm{AC} 2$ & $900: 2: 2$ & 1212 & 1132 & 80 & 93.4 & 6.6 & 0.78 & 35.1 \\
\hline AC3 & $800: 2: 1.5$ & 1181 & 935 & 246 & 79.2 & 20.8 & 0.68 & 37.7 \\
\hline $\mathrm{AC} 4$ & $700: 3: 1.5$ & 1316 & 1152 & 164 & 87.5 & 12.5 & 0.80 & 39.0 \\
\hline AC5 & $800: 2: 1.5$ & 1344 & 1008 & 226 & 75.0 & 25.0 & 0.69 & 40.3 \\
\hline AC6 & $700: 2: 2$ & 1346 & 1311 & 35 & 97.4 & 2.6 & 0.87 & 41.0 \\
\hline $\mathrm{AC} 7$ & $800: 2: 1.5$ & 1298 & 1122 & 222 & 86.4 & 13.6 & 0.76 & 39.0 \\
\hline AC8 & $800: 3: 2$ & 1185 & 68 & 1117 & 5.7 & 94.3 & 0.74 & 40.3 \\
\hline AC9 & $800: 3: 1$ & 1067 & 526 & 541 & 49.3 & 50.7 & 0.42 & 30.3 \\
\hline AC10 & $900: 2: 1$ & 1018 & 562 & 456 & 55.2 & 44.8 & 0.56 & 40.7 \\
\hline AC11 & $700: 2: 1$ & 1196 & 564 & 632 & 47.2 & 52.8 & 0.63 & 38.3 \\
\hline $\mathrm{AC} 12$ & $800: 1: 2$ & 1294 & 1244 & 49 & 96.1 & 3.9 & 0.83 & 38.5 \\
\hline AC13 & $800: 1: 1$ & 739 & 385 & 354 & 52.1 & 47.9 & 0.56 & 38.6 \\
\hline $\mathrm{AC} 14$ & $700: 1: 1.5$ & 1374 & 1124 & 251 & 81.8 & 18.2 & 0.80 & 31.5 \\
\hline AC15 & $900: 3: 1.5$ & 1076 & 207 & 869 & 19.2 & 80.8 & 0.63 & 30.1 \\
\hline
\end{tabular}

All produced ACs, regardless of experimental conditions, exhibited high $S_{\text {BET }}$ values (Table 2). The highest $S_{\text {BET }}$ value of $1374 \mathrm{~m}^{2} \mathrm{~g}^{-1}$ was obtained through pyrolysis at $700{ }^{\circ} \mathrm{C}$ for $1 \mathrm{~h}$ and $\mathrm{a} \mathrm{ZnCl}_{2}$ /bark ratio of 1.5 (AC14). This AC preparation condition corresponded to the lowest temperature and holding time and the mid-level for the $\mathrm{ZnCl}_{2}$ /bark ratio in the experimental design. Also, ACs with $\mathrm{S}_{\mathrm{BET}}$ above 1300 $\mathrm{m}^{2} \mathrm{~g}^{-1}$ were generated at three other experimental conditions (see Table 2), indicating that spruce bark is a promising and feasible precursor for producing ACs with high specific surface areas and well-developed porosities using different conditions.

As indicated by $\mathrm{S}_{\mathrm{MESO}}$ and $\mathrm{S}_{\mathrm{MESO}}$ values, the spruce bark ACs showed mesoporous structures; for instance, the percentage of mesopores (with relation to $\mathrm{S}_{\mathrm{BET}}$ values) of AC6, AC12, and AC2 was 97.4\%, 96.1\%, and 93.4\%, respectively. The presence of mesopores is highly desirable in ACs for adsorption and energy storage applications because they ensure wetting and liquid transport throughout the bulk of the $\mathrm{AC}[2,3,9,10]$. In contrast, $\mathrm{AC} 8$ (prepared at $800{ }^{\circ} \mathrm{C}$, $3 \mathrm{~h}, \mathrm{ZnCl}_{2}$ /bark ratio of 1) and $\mathrm{AC} 15$ (prepared at $900{ }^{\circ} \mathrm{C}$, $3 \mathrm{~h}, \mathrm{ZnCl}_{2}$ /bark ratio of 1.5 ) exhibited highly microporous structures: $94.3 \%$ and $80.8 \%$ of the total $\mathrm{S}_{\mathrm{BET}}$, respectively.

Comparing the obtained results in Table 2 with international literature, Dos Reis et al. [11] produced ACs from sewage sludge and reported $S_{B E T}$ values up to $679 \mathrm{~m}^{2} \mathrm{~g}^{-1}$. Danish et al. [32] used Acacia mangium wood to make AC and reported an $\mathrm{S}_{\mathrm{BET}}$ of $1767 \mathrm{~m}^{2} \mathrm{~g}^{-1}$, with $95 \%$ of the total surface area as mesopores. In another work, Li et al. [20] prepared ACs from Chinese chestnut burs; the highest $\mathrm{S}_{\mathrm{BET}}$ was $1254.5 \mathrm{~m}^{2} \mathrm{~g}^{-1}$ with a microporosity ratio of $87.2 \%$.
Bouchelta et al. [33] produced ACs from biomass of Algerian date pits with high-developed microporosity. The AC with the highest $\mathrm{S}_{\mathrm{BET}}\left(1467 \mathrm{~m}^{2} \mathrm{~g}^{-1}\right)$ was obtained at $700{ }^{\circ} \mathrm{C}$ and $4 \mathrm{~h}$ of holding time. They concluded that increasing the holding time favoured the development of microporosity and led to high $\mathrm{S}_{\mathrm{BET}}$ values. Mistar et al. [34] synthesised ACs from yellow bamboo (Bambusa vulgaris "Striata"), and all prepared ACs presented predominantly microporous structures. The AC's microporosity increased significantly with pyrolysis temperature and chemical activator ratio.

Galiatsatou et al. [35] used olive pulp and peach stones as precursors for AC preparation and concluded that extended holding times favoured mesopore development. $\mathrm{Hu}$ et al. [36] reported that high chemical ratios, long holding times, and high temperatures increase the mesoporosity in ACs. They suggested that a high $\mathrm{ZnCl}_{2}$ /biomass ratio creates new mesopores by widening the micropores.

The $\mathrm{S}_{\mathrm{BET}}$ values of the AC samples in this study increased as follows: AC13<AC10<AC1 < AC9 < AC $15<\mathrm{AC} 3<\mathrm{AC} 8<\mathrm{AC} 11<\mathrm{AC} 2<\mathrm{AC} 12<\mathrm{AC} 7<\mathrm{AC} 4<$ AC5 < AC6 < AC14, while the mesoporosity increased from AC8 < AC15 < AC11 < AC9 < AC10 < AC7 < AC5 $<\mathrm{AC} 3<\mathrm{AC} 14<\mathrm{AC} 1<\mathrm{AC} 7<\mathrm{AC} 4<\mathrm{AC} 2<\mathrm{AC} 12<\mathrm{AC}$ 6 . By these results, it is difficult to establish correlations between $S_{B E T}$ values and single pyrolysis parameters, but by applying the DoE data analysis methodology, it is possible to clarify the relations between experimental factors and $\mathrm{S}_{\mathrm{BET}}$ and micro-mesoporosity formation. These results are presented in the following section. 


\subsection{Response surface plots, influence of the factors, and statistical analysis}

\subsubsection{Response surface plots}

The response-contour surface plot is a valuable and visual tool for understanding how selected factors affect the studied responses by providing a "map" of the fitted model's response values at all possible settings within the range of the experimental design. However, it is important to remember that the visuals represent model data, not experimental values, to avoid overinterpretation of results and underestimating model errors.

Figure 1A-I show trends for the factors' effects and their interactions on the specified responses for the ACs. In addition, optimum conditions can be found within the region with the highest response values. ACs with the highest $\mathrm{S}_{\mathrm{BET}}$ are obtained at shorter activation holding times, low pyrolysis temperatures, and high $\mathrm{ZnCl}_{2} /$ bark ratios (see Fig. 1A-C). In more detail, ACs with the highest $S_{\text {BET }}$ values are obtained at holding times no longer than $2.5 \mathrm{~h}$, pyrolysis temperatures no higher than $800{ }^{\circ} \mathrm{C}$, and a $\mathrm{ZnCl}_{2}$ /bark ratio up to 2.0.

The highest mesopore surface area $\left(\mathrm{S}_{\mathrm{MESO}}\right)$ is obtained at pyrolysis temperatures up to $800^{\circ} \mathrm{C}$, holding times up to $2 \mathrm{~h}$, and $\mathrm{ZnCl}_{2}$ /bark ratios around 1.5-2 (see Fig. 1D-F). High micropore surface areas $\left(\mathrm{S}_{\mathrm{MICRO}}\right)$ require longer activation holding times (close to $3 \mathrm{~h}$ ) and a pyrolysis temperature up to $800{ }^{\circ} \mathrm{C}$. Here, the effect of the $\mathrm{ZnCl}_{2}$ /bark ratio is more challenging to interpret due to possible interaction effects (see Fig. 1G-I).

Surface contour plots show the behaviour of the studied factors on the $\mathrm{S}_{\mathrm{BET}}$, $\mathrm{S}_{\mathrm{MESO}}$, and $\mathrm{S}_{\mathrm{MICRO}}$ responses; however, elucidating factor and interaction importance need additional analysis. For this purpose, Pareto charts and normal plots are used and analysed in the below section.
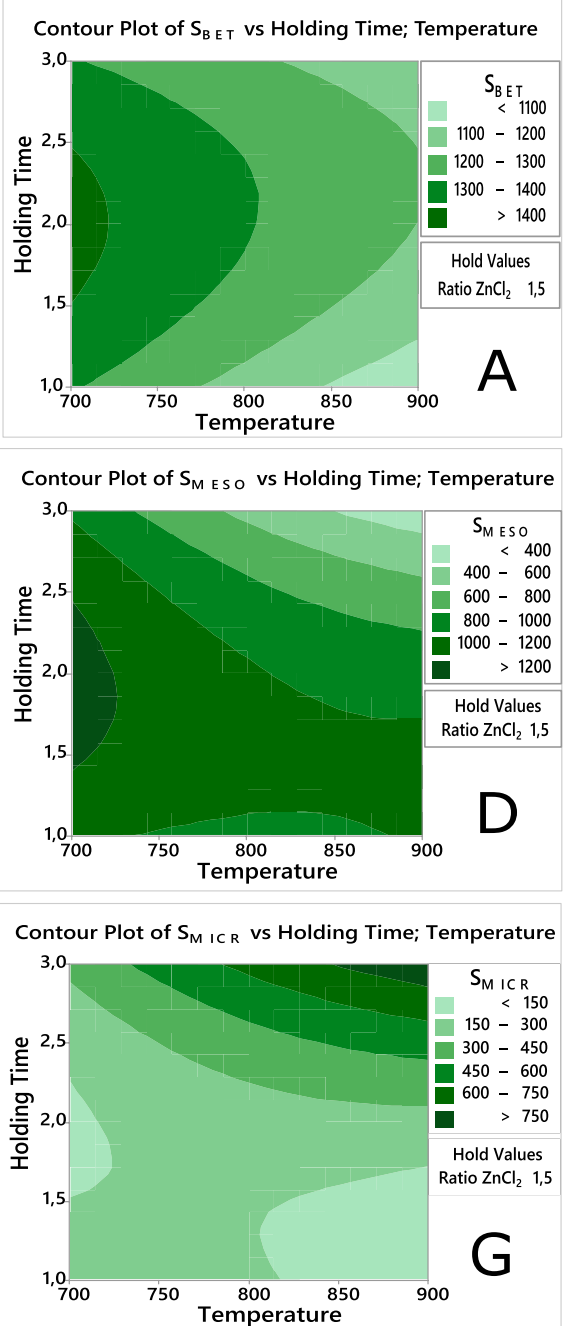
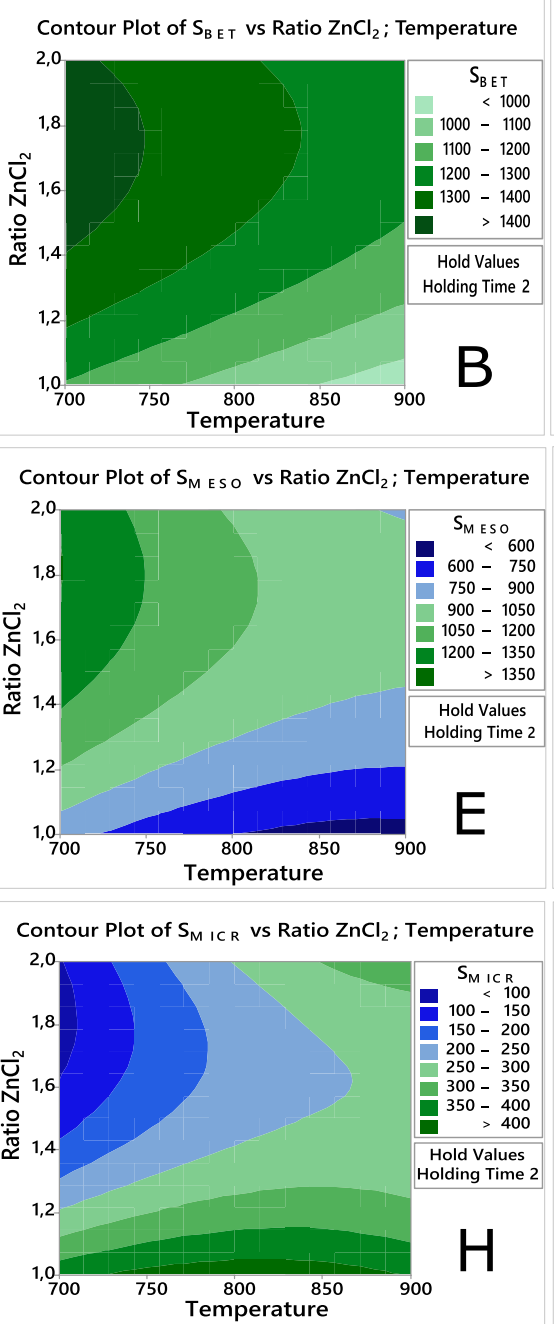

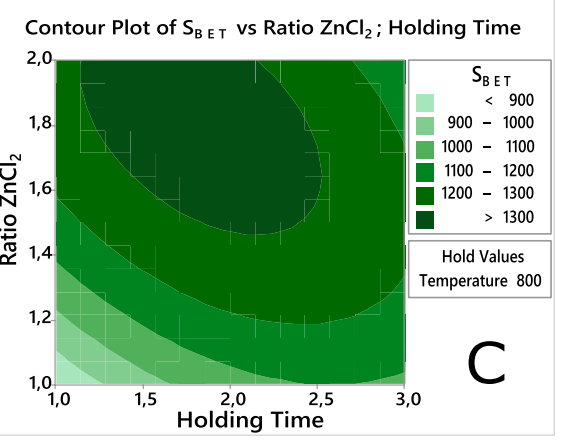

Contour Plot of $\mathrm{S}_{\mathrm{M} \text { E So }}$ vs Ratio $\mathrm{ZnCl}_{2}$; Holding Time

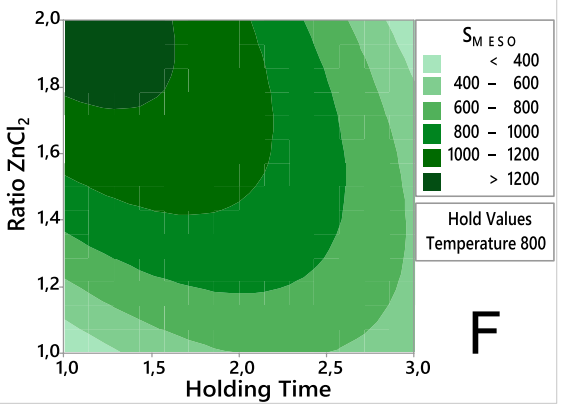

Contour Plot of $\mathrm{S}_{\mathrm{M} I C \mathrm{R}}$ vs Ratio $\mathrm{ZnCl}_{2}$; Holding Time

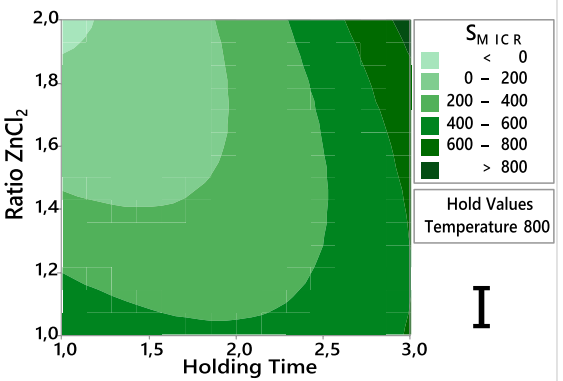

Fig. 1 Contour plots for effects of pyrolysis temperature, holding time, and $\mathrm{ZnCl}_{2} /$ bark ratio on $\mathrm{S}_{\mathrm{BET}}(\mathbf{A}-\mathbf{C}), \mathrm{S}_{\mathrm{MESO}}(\mathbf{D}-\mathbf{F})$, and $\mathrm{S}_{\mathrm{MICRO}}(\mathbf{G}-\mathbf{I})$ 


\subsubsection{Pareto charts and normal plots}

From experimental results, the effects of the factors and their interactions on the $\mathrm{S}_{\mathrm{BET}}$, $\mathrm{S}_{\mathrm{MESO}}$, and $\mathrm{S}_{\mathrm{MICRO}}$ can be statistically evaluated by use of a Pareto chart; it aims to graphically demonstrate the significance and the relationship of the studied factors on the related responses $[11,13,15]$. The bars visualise the factors and their interactions [11]. The dotted line is associated with the $p$-value [11]; the factors or interactions that exceed this line have a statistically significant effect on the studied response [11]. Therefore, for the $\mathrm{S}_{\mathrm{BET}}$ response, the Pareto chart (Fig. 2A) shows that the $\mathrm{ZnCl}_{2}$ /bark ratio (C), followed by pyrolysis temperature (A), is statistically significant $(\alpha=0.05)$ factors while holding time (B) in the studied range does not influence the $S_{\mathrm{BET}}$ values significantly. The square for the factors $\mathrm{ZnCl}_{2} /$ bark ratio (CC) and holding time (BB) and the interaction between holding time and $\mathrm{ZnCl}_{2}$ /bark ratio (BC) have significant but weak effects on the $\mathrm{S}_{\mathrm{BET}}$. For the $\mathrm{S}_{\mathrm{MESO}}$, the interaction between holding time and $\mathrm{ZnCl}_{2} /$ bark ratio (BC) is the most critical factor (Fig. 2B), while for $\mathrm{S}_{\text {MICRO }}$, holding time (B) is the most influential. All other factors with $t$-test values that do not cross the reference line are statistically insignificant $(\alpha=0.05)[11,13]$.

Morali U et al. [36] optimised the preparation of AC from sunflower seed extracted meal using DoE. They concluded that the $\mathrm{ZnCl}_{2}$ /biomass ratio was one of the most influential factors for the $\mathrm{S}_{\mathrm{BET}}$ values of the ACs. In another work, dos Reis et al. [11] used DoE to optimise the AC textural properties and similarly found that the ratio of $\mathrm{ZnCl}_{2}$ played a crucial role for the $\mathrm{S}_{\mathrm{BET}}$ values. In carbon activation, $\mathrm{ZnCl}_{2}$ is intercalated into the carbon matrix to produce pores at temperatures above its melting point, which act as templates to create and develop porosity $[35,36]$. The melted $\mathrm{ZnCl}_{2}$ expands the existing micropores into mesopores leading to a higher $\mathrm{S}_{\mathrm{BET}}[35,36]$. Moreover, in this activation process, reactions between the carbon atoms in the precursor material and $\mathrm{ZnCl}_{2}$ in extended carbon interlayers contribute to creating pores $[9,35]$. In addition, $\mathrm{ZnCl}_{2}$ chemical activation increases the carbon content by forming an aromatic graphitic structure, leading to a higher $\mathrm{S}_{\mathrm{BET}}$.

The Pareto chart helps to identify the factors and interactions most decisive for a selected response [11]. However, it does not show if the effect is positive or negative; a normal
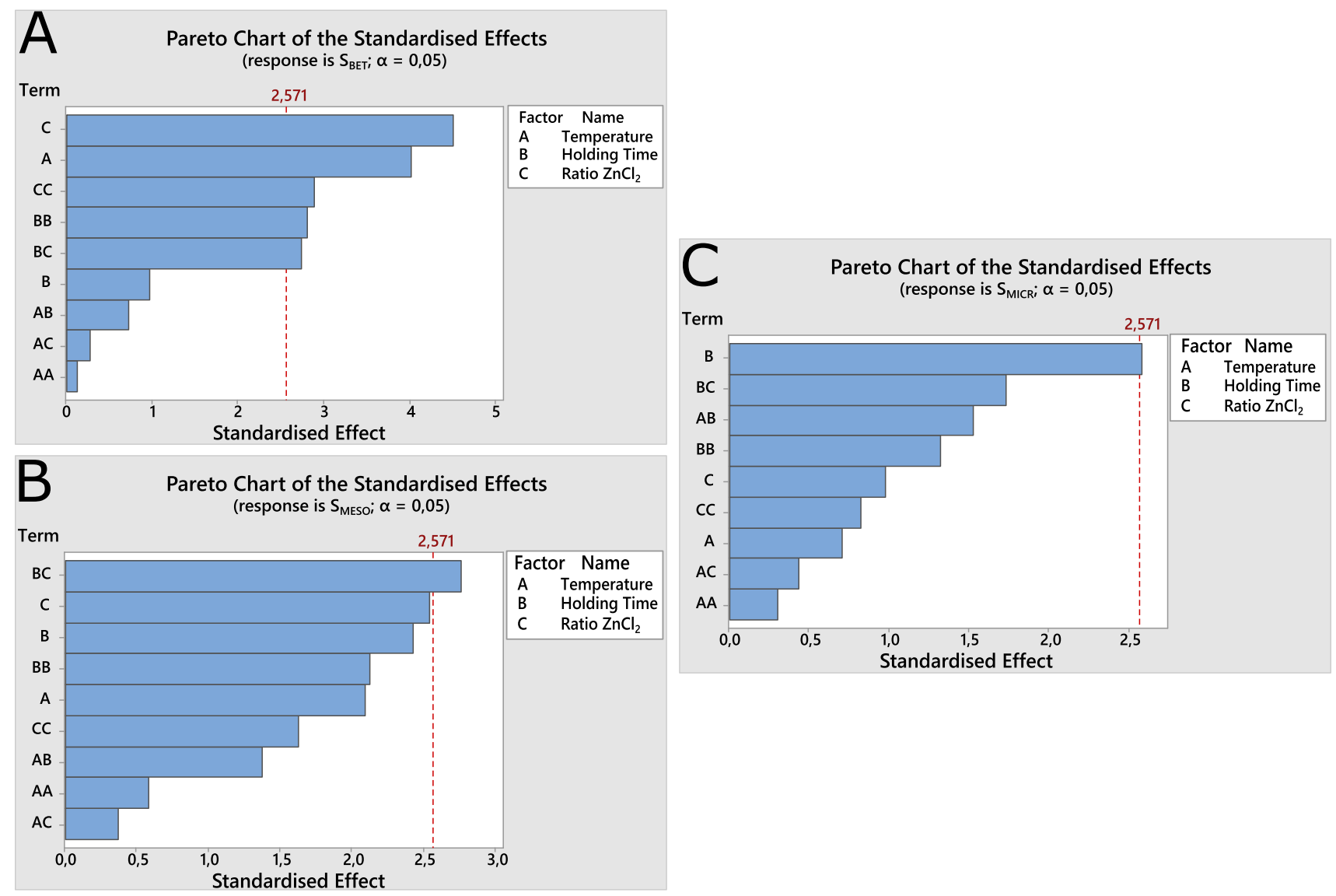

Standardised Effect

Fig. 2 Pareto charts of the standardised effects of pyrolysis temperature, holding time, and the ratio of $\mathrm{ZnCl}_{2}$ on $\mathbf{A} \mathrm{S}_{\mathrm{BET}}$, $\mathbf{B} \mathrm{S}_{\mathrm{MESO}}$, and $\mathbf{C ~ \mathrm { S } _ { \mathrm { MICRO } }}$ for the AC preparation (at a minimum statistically significant level of $95 \%$ confidence) 
plot provides such information (see Fig. 3). In the normal plot, the significant factors are labelled with red symbols; those that negatively affect the response are situated far to the left of the fit line and vice versa [11]. Consequently, high temperature decreases the $\mathrm{S}_{\mathrm{BET}}$ (Fig. 3A), and a long holding time increases the micropore area (Fig. 3C). A high $\mathrm{ZnCl}_{2}$ /bark ratio increases the $\mathrm{S}_{\mathrm{BET}}$ values (Fig. 3A), and interactions between holding time and the $\mathrm{ZnCl}_{2} /$ bark ratio increase the mesopore area. The remaining factors and their interactions have no statistically significant effects $(\alpha=0.05)$ on the responses under the studied conditions.

Our results agree with previous literature, showing that the concentration of $\mathrm{ZnCl}_{2}$ during activation substantially affects the $\mathrm{S}_{\mathrm{BET}}$ values of the ACs $[5-8,37,38]$. This result is reasonable because when the $\mathrm{ZnCl}_{2}$ /precursor ratio increases, more metallic ions are complexed with the functional groups present in the biomass during the mixing step (between biomass and $\mathrm{ZnCl}_{2}$ ) [39, 40]. After pyrolysis, the inorganic compounds occupy a considerable volume of the carbonaceous matrix. When these inorganics are leached out during the $\mathrm{HCl}$ washing step, the resulting $\mathrm{AC}$ materials display well-developed pore network structures and high $\mathrm{S}_{\mathrm{BET}}[39,40]$.

In addition, the negative effect of the temperature on the $\mathrm{S}_{\mathrm{BET}}$ is also reported in the literature [11, 41]. The authors concluded that increased pyrolysis temperatures induce shrinkage of the carbon structure, resulting in a reduction in $\mathrm{S}_{\mathrm{BET}}$ and pore volume. This finding is also reported by several researchers, which showed a negative effect of pyrolysis temperature on the $\mathrm{S}_{\mathrm{BET}}[3,8,21,25]$.

\subsection{AC preparation: comparison with literature}

Any precursor rich in carbon can be converted to activated carbon with tailored properties targeting different applications such as adsorbents, catalysts, and anodes for energy storage devices. However, to produce an efficient AC, careful considerations of pyrolysis conditions must be made since the conditions play an essential role in the final AC's characteristics. Moreover, robust optimisation studies are required to make the production process sustainable and environmentally friendly.
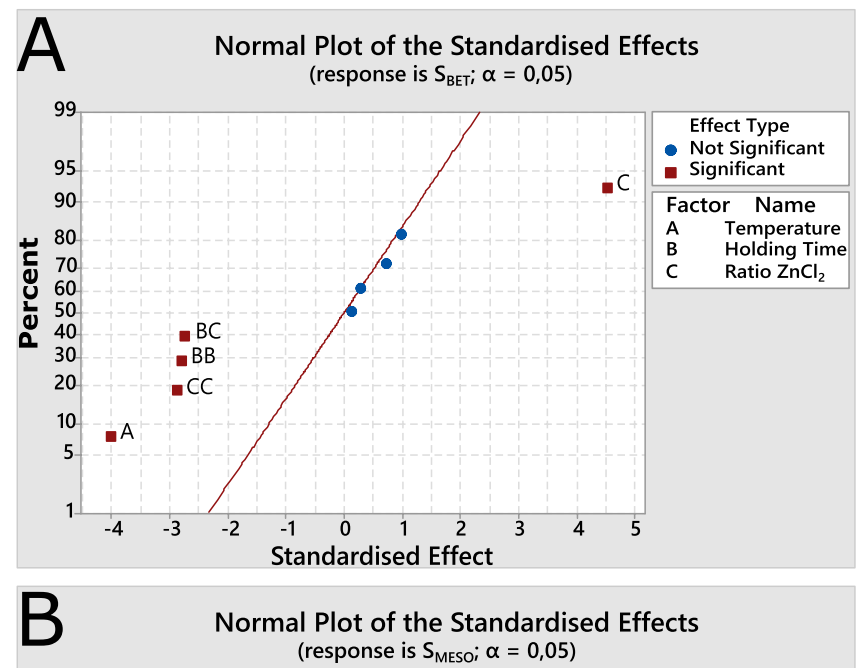

Normal Plot of the Standardised Effects (response is $\mathrm{S}_{\mathrm{MESO}} ; \alpha=0,05$ )

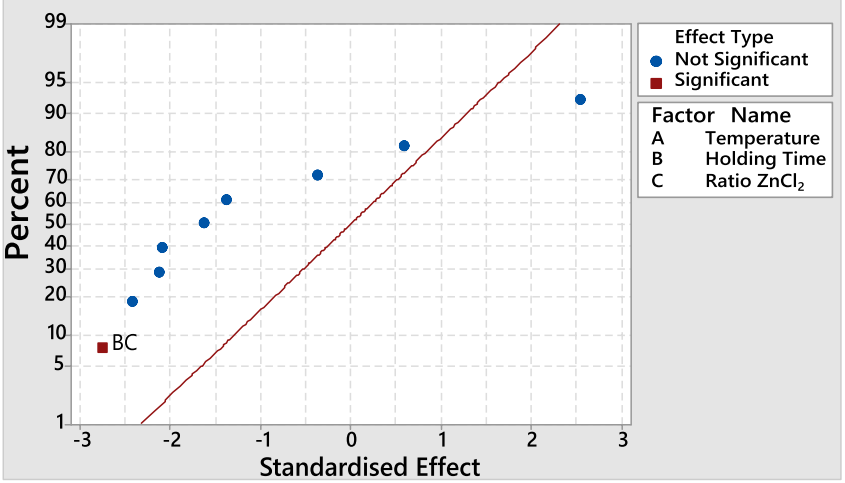

Fig. 3 Normal plots of the standardised effects of pyrolysis temperature, holding time, and the ratio of $\mathrm{ZnCl}_{2}$ on $\mathbf{A} \mathrm{S}_{\mathrm{BET}}$, $\mathbf{B} \mathrm{S}_{\mathrm{MESO}}$, and $\mathbf{C}$ $\mathrm{S}_{\mathrm{MICRO}}$ for the $\mathrm{AC}$ preparation (at a minimum statistically significant

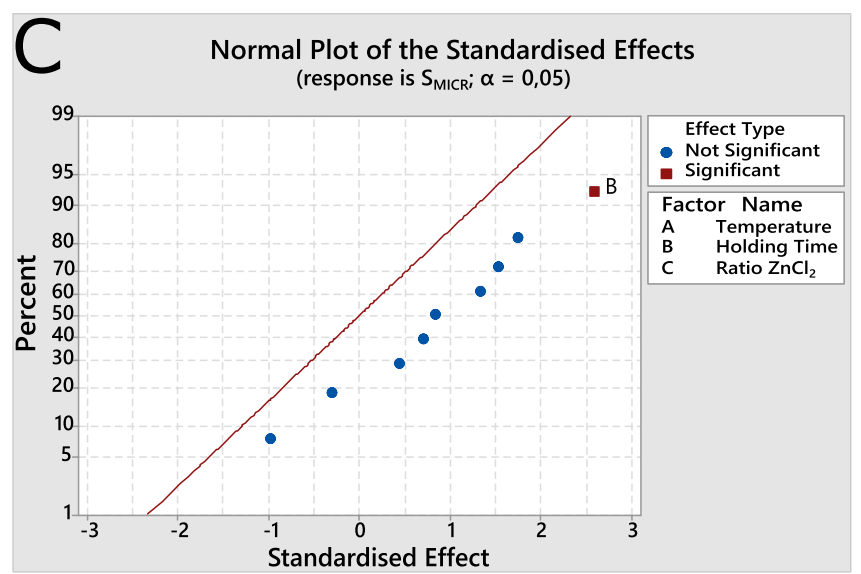

level of $95 \%$ confidence). Negative and positive effects are separated at the $50 \%$ level 
DoE has been used to optimise AC preparation in several previous studies (see Table 3). Comparing the results obtained in this work with international literature gives a more accurate evaluation of whether the DoE was applied and appropriately conducted and how effective it can be to optimise the preparation of porous AC. For an efficient comparison, the optimisation of the production of ACs, using several different DoE, is displayed in Table 3.

Table 3 shows that the pyrolysis temperature, holding time, and chemical/precursor ratio are the most studied factors, and $\mathrm{S}_{\mathrm{BET}}$ is the most evaluated response. A large variety of carbon precursors have been treated under different preparation conditions. Table 4 shows a considerable variation in response values (especially for $\mathrm{S}_{\mathrm{BET}}$ ) with biomass precursors and preparation conditions.

Abioye et al. [42] employed a DoE Box-Behnken design (with 15 runs in total) to optimise oil palm shell ACs' textural properties. Three factors were evaluated: pyrolysis temperature: $800,850,900{ }^{\circ} \mathrm{C}$; holding time: $20,30,40 \mathrm{~min}$; and $\mathrm{CO}_{2}$ flow rate: $200,300,400 \mathrm{~cm}^{3} \mathrm{~min}^{-1}$. Two responses were analysed: $\mathrm{S}_{\mathrm{BET}}$ and micropore volume, $\mathrm{S}_{\mathrm{MICRO}}$. The authors found that the holding time had the most profound effects on $S_{\text {BET }}$ and $S_{\text {MICRO }}$ values [42]. Also, the $S_{\text {BET }}$ values ranged from 291 to $574 \mathrm{~m}^{2} \mathrm{~g}^{-1}$. The optimum condition was identified as $900{ }^{\circ} \mathrm{C}, 40 \mathrm{~min}$, and $\mathrm{CO}_{2}$ flow rate: 400 $\mathrm{cm}^{3} \min ^{-1}$.

dos Reis et al. [11] used DoE (a full factorial design with 12 runs in total) to optimise the production of ACs from sewage sludge through conventional and microwave heating methods. The authors evaluated three factors with $\mathrm{S}_{\mathrm{BET}}$ as the response. The factors were pyrolysis temperature or microwave power, holding time, and chemical activator proportion. Factor conditions were temperature (500, $\left.650,800^{\circ} \mathrm{C}\right)$, microwave power $(700,840,980 \mathrm{~W})$, holding time $(15,37.5$, and $60 \mathrm{~min}$ for conventional pyrolysis and 8,10, and 12 min for the microwave methods), and the $\mathrm{ZnCl}_{2}$ :sludge ratio $(0.5,1.0$, and 1.5$)$. The optimum factor combination for producing $\mathrm{AC}$ with the highest surface area was found at $500{ }^{\circ} \mathrm{C}, 15 \mathrm{~min}$, and a $\mathrm{ZnCl}_{2}$ : sludge ratio of 0.5 for conventional pyrolysis, while it was $980 \mathrm{~W}, 12 \mathrm{~min}$, and a $\mathrm{ZnCl}_{2}$ :sludge ratio of 0.5 for microwave pyrolysis. The optimal conditions generated ACs with $\mathrm{S}_{\mathrm{BET}}$ values of $679 \mathrm{~m}^{2} \mathrm{~g}^{-1}$ and $501 \mathrm{~m}^{2} \mathrm{~g}^{-1}$ for conventional and microwave pyrolysis, respectively. The most critical factors for conventional pyrolysis were temperature and the interaction between pyrolysis temperature, holding time, and chemical activator. The interaction between radiation power, holding time, and the chemical activator ratio was the most influential for microwave pyrolysis.

Comparing our results with the literature data (Table 3 ) reveals that ACs with very high $\mathrm{S}_{\mathrm{BET}}$ and well-developed mesoporosity can be produced from Norway spruce bark under optimal pyrolysis conditions. The literature on AC production covers a plethora of precursors and experimental matrices of pyrolysis conditions and activation methods. It is not always possible to compare the results from different studies, but it is safe to conclude that the optimum methodology varies with the precursor properties. Also, further systematic studies are needed to increase the knowledge on how suitable combinations of biomass precursors, pyrolysis conditions, and chemical activation procedures to obtain ACs with textural and functional properties for specific applications.

\subsection{Chemical characterisation and morphology of the activated carbons}

\subsubsection{Elementary analysis}

Table 4 shows the results for the elemental composition of the prepared ACs. For comparison, a typical commercial $\mathrm{AC}$ has $88 \%$ of $\mathrm{C}, 0.5 \%$ of $\mathrm{H}, 0.5 \%$ of $\mathrm{N}$, and $3-4 \%$ ash [47]. All ACs prepared from spruce bark through $\mathrm{ZnCl}_{2}$ activation had a C content above 93\% (Table 5), which can be considered a high value compared with the literature. For example, Correa et al. [47] employed a range of different biomasses, based on alpha-cellulose, xylan, kraft lignin, to produce $\mathrm{ACs}$, and their $\mathrm{C}$ content varied from 76.9 to $87.8 \%$. In another work [48], coconut shell was used to prepare ACs, and the highest $\mathrm{C}$ content was $82.66 \%$. High carbon content reflects good AC characteristics due to the carbon's physicochemical, electrical, and thermal properties. Also, an elevated $\mathrm{C}$ content is often a sign of low ash content, and ashes in $\mathrm{AC}$ are often responsible for reducing $\mathrm{S}_{\mathrm{BET}}$ and surface functionalities. Surface functionality is vital for many AC applications, such as adsorption of pollutants in waters and as electrode materials in energy storage systems.

The prepared ACs had relatively high oxygen content. This feature may reflect a high hydrophilicity index, a good quality for $\mathrm{AC}$ applications in solid/liquid systems [47]. In addition, the ACs had high $\mathrm{C} / \mathrm{O}$ ratios, which indicates the formation of hydroxyl groups on the AC surfaces (this was analysed by XPS analysis and discussed in the following section). Also, high $\mathrm{C} / \mathrm{O}$ ratios indicate that the spruce bark AC structures are similar to near-perfect graphene layers. Sample AC15 had the highest (57.3) and AC14 the lowest (33.7) $\mathrm{C} / \mathrm{O}$ values.

\subsubsection{X-ray photoelectron spectroscopy (XPS)}

The elemental composition and chemical state of the ACs were analysed with XPS. It was employed to understand AC surface chemistry and assess the effects of the $\mathrm{ZnCl}_{2}$ treatment and the relationship between spruce bark composition and pyrolysis conditions. Four AC samples (AC1, AC9, AC13, and AC14) were studied (Fig. 4). The samples were 


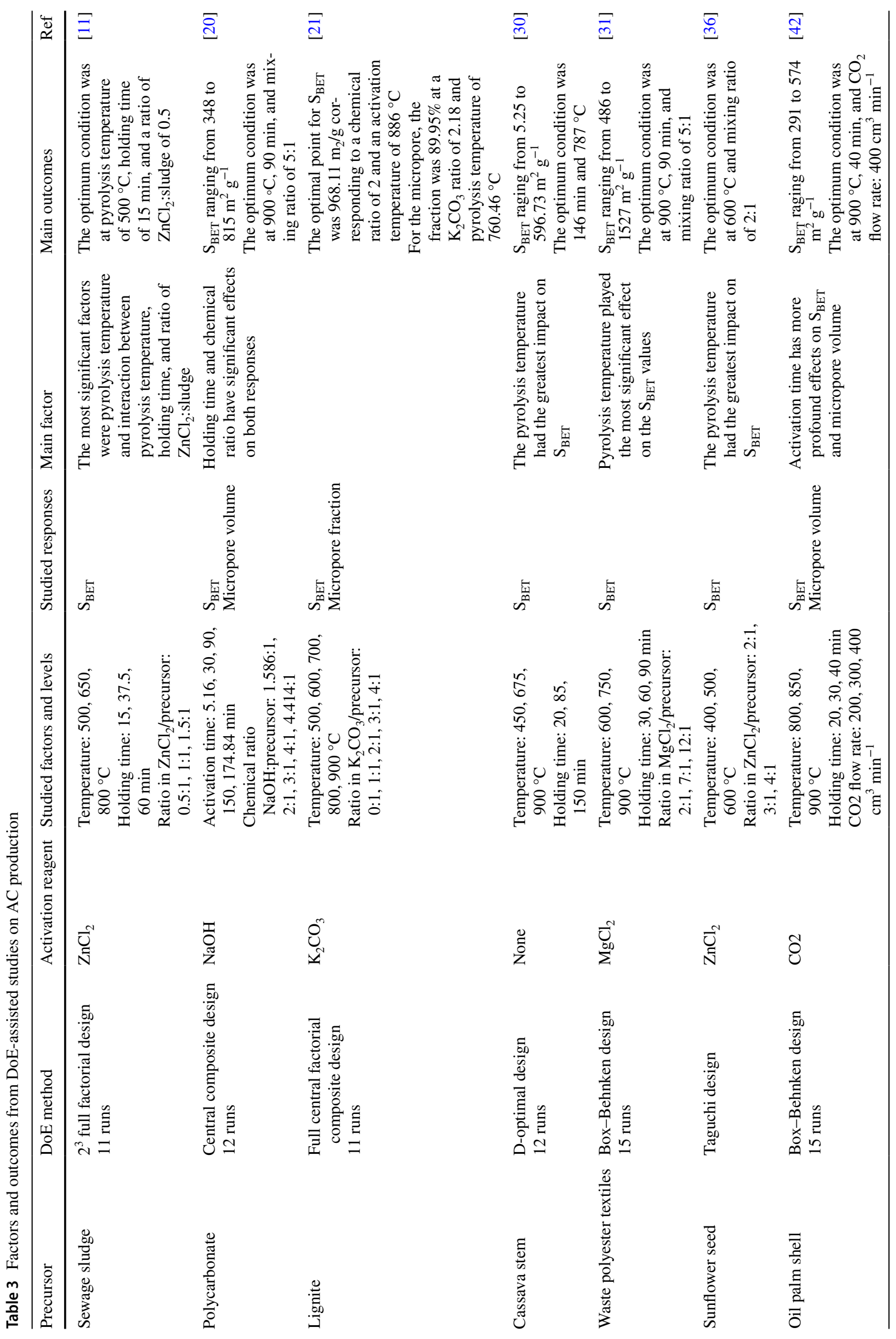




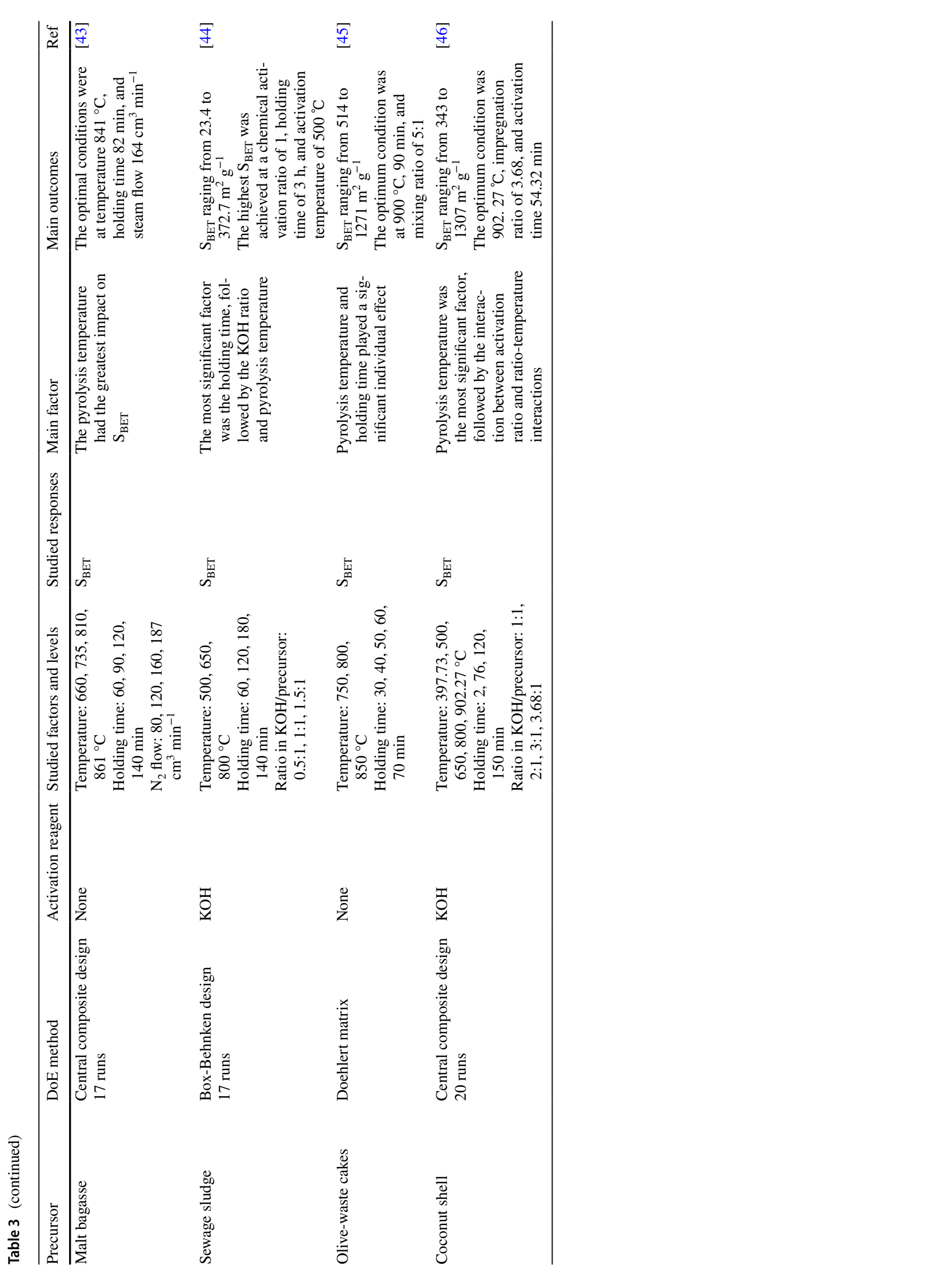


Table 4 Elemental composition of the spruce bark ACs

\begin{tabular}{llllllll}
\hline Sample name & $\mathrm{C}(\%)$ & $\mathrm{N}(\%)$ & $\mathrm{H}(\%)$ & $\mathrm{O}(\%)$ & Ash $(\%)$ & $\mathrm{C} / \mathrm{N}$ & $\mathrm{C} / \mathrm{O}$ \\
\hline AC1 & 93.7 & 0.51 & 0.79 & 2.11 & 2.9 & 183 & 44.4 \\
AC2 & 93.4 & 0.52 & 1.20 & 2.38 & 2.5 & 179 & 39.2 \\
AC3 & 94.5 & 0.46 & 0.98 & 2.12 & 1.9 & 205 & 44.6 \\
AC4 & 93.4 & 0.43 & 0.95 & 2.27 & 2.9 & 217 & 41.1 \\
AC5 & 94.5 & 0.44 & 0.88 & 2.18 & 2.0 & 214 & 43.3 \\
AC6 & 93.6 & 0.42 & 1.10 & 2.13 & 2.7 & 222 & 43.9 \\
AC7 & 93.3 & 0.43 & 1.12 & 1.94 & 3.2 & 222 & 48.1 \\
AC8 & 93.3 & 0.43 & 0.99 & 1.87 & 3.4 & 217 & 49.9 \\
AC9 & 94.0 & 0.50 & 0.98 & 2.02 & 2.5 & 188 & 46.5 \\
AC10 & 93.2 & 0.64 & 1.18 & 2.65 & 2.3 & 145 & 35.2 \\
AC11 & 93.9 & 0.50 & 1.11 & 2.38 & 2.1 & 187 & 39.5 \\
AC12 & 93.8 & 0.49 & 0.99 & 2.20 & 2.5 & 191 & 42.6 \\
AC13 & 94.8 & 0.50 & 1.13 & 2.47 & 1.1 & 189 & 38.4 \\
AC14 & 93.3 & 0.43 & 1.02 & 2.77 & 2.5 & 217 & 33.7 \\
AC15 & 94.5 & 0.42 & 1.06 & 1.65 & 2.4 & 225 & 57.3 \\
\hline
\end{tabular}

Table 5 XPS spectral deconvolution (at \%) of $\mathrm{AC} 1$, $\mathrm{AC} 9, \mathrm{AC} 13$, and $\mathrm{AC} 14$

\begin{tabular}{|c|c|c|c|c|c|c|}
\hline \multirow[b]{2}{*}{ Samples } & \multirow[b]{2}{*}{$\mathrm{C} 1 \mathrm{~s}$} & \multirow[b]{2}{*}{$\mathrm{O} 1 \mathrm{~s}$} & \multirow[b]{2}{*}{$\mathrm{C} / \mathrm{O}$} & \multicolumn{3}{|l|}{ O1s } \\
\hline & & & & $\mathrm{C}=\mathrm{O}$ & $\mathrm{C}-\mathrm{OH}, \mathrm{C}-\mathrm{O}-\mathrm{C}$ & $\pi-\pi^{*}$ excitation \\
\hline $\mathrm{AC} 1$ & 94.8 & 5.0 & 19.0 & 1.46 & 2.80 & 0.73 \\
\hline AC9 & 94.7 & 4.9 & 19.2 & 1.24 & 3.02 & 0.67 \\
\hline $\mathrm{AC} 13$ & 94.7 & 4.4 & 21.4 & 1.51 & 2.21 & 0.70 \\
\hline AC14 & 94.5 & 5.2 & 18.2 & 2.10 & 2.40 & 0.70 \\
\hline
\end{tabular}

selected based on their $\mathrm{S}_{\mathrm{BET}}$ values (from lowest (AC13) to highest (AC14) and two in between (AC1 and AC9).

As can be seen, Fig. 4 shows spectra related to $\mathrm{C} 1 \mathrm{~s}$ and O1s, carbon and oxygen bonds, respectively [14, 49, 50]. The deconvolution of the $\mathrm{C} 1 \mathrm{~s}$ spectrum indicates that all samples contain graphitic/aromatic $\mathrm{C}=\mathrm{C}$ or hydrocarbon $\mathrm{C}-\mathrm{C}(\sim 284.3 \mathrm{eV}), \mathrm{C}-\mathrm{O}$ in phenolic hydroxyl or ether groups $(\sim 286.5 \mathrm{eV})$, carbonyl C-O $(\sim 287.5 \mathrm{eV})$, and ester $\mathrm{O}=\mathrm{C}-\mathrm{O}$ $(\sim 289.1 \mathrm{eV})$, graphitic carbon being the major component [49].

O1s spectra were deconvoluted to three chemical oxygen states with binding energies at around $530.8-531.2 \mathrm{eV}$, $532.6-533.1 \mathrm{eV}$, and 534.8-536.3 eV. These binding energies could correspond to oxygen singly bonded to carbon in aromatic rings, in phenols and ethers $(533.2-533.8 \mathrm{eV})$, or to oxygen double-bonded with carbon in carbonyl and quinone-like structures $(530.8-531.2 \mathrm{eV})$ [51], confirming the presence of some functional groups on the ACs' surfaces.

The quantitative information from XPS is shown in Table 5. The surface $\mathrm{C}$ content of all four ACs did not vary significantly (from 94.5 to $94.8 \%$ ). In contrast, the $\mathrm{O}$ content showed a larger variation (from 4.4 to $5.2 \%$ ), and the values match the values presented by elementary analysis (see Table 4). The highest O1s content $(5.2 \%)$ was found in the AC14 sample, suggesting that this sample had more functionalities when compared to the others, especially for functional groups related to $\mathrm{C}=\mathrm{O}, \mathrm{C}-\mathrm{OH}$, and $\mathrm{C}-\mathrm{O}-\mathrm{C}$ (see Table 5). The AC14 sample had the highest $\mathrm{S}_{\mathrm{BET}}$ and amount of functional groups, suggesting high efficiency as an adsorbent for water decontamination and electrode material for energy storage systems $[2,9,18,37]$.

\subsubsection{Raman spectroscopy}

Raman spectroscopy analysis was performed to evaluate the degree of graphitisation of the prepared ACs. Using Raman, it was possible to determine the ratio of the $\mathrm{I}_{\mathrm{D}} /$ $\mathrm{I}_{\mathrm{G}}$ bands (see Fig. 5). The lower $\mathrm{I}_{\mathrm{D}} / \mathrm{I}_{\mathrm{G}}$ value indicates that ACs exhibit more perfect and orderly graphite structures with a high graphitisation degree [52-54], while a higher $\mathrm{I}_{\mathrm{D}} / \mathrm{I}_{\mathrm{G}}$ peak intensity ratio reveals more structural defects in carbon materials. Moreover, $\mathrm{I}_{\mathrm{D}} / \mathrm{I}_{\mathrm{G}}$ values also serve to identify the size of the $\mathrm{sp}^{2}$ domain, related to graphene structure, in the AC structure $[53,55]$. Figure 5 shows that AC6 $\left(700{ }^{\circ} \mathrm{C}, 2 \mathrm{~h}, 2\right)$ had the highest graphitisation degree, followed by AC14 $\left(700{ }^{\circ} \mathrm{C}, 1 \mathrm{~h}, 1.5\right)$ - presenting $\mathrm{I}_{\mathrm{D}} / \mathrm{I}_{\mathrm{G}}$ values of 0.85 and 0.88 , respectively. These values indicate that both samples (AC6 and AC14) had highly disordered structures. Interestingly, these samples also presented $\mathrm{S}_{\mathrm{BET}}$ values among the highest in the experimental design: 1343 
Fig. 4 XPS C1s and O1s spectra of $\mathrm{AC} 1, \mathrm{AC} 9, \mathrm{AC} 13$, and $\mathrm{AC} 14$
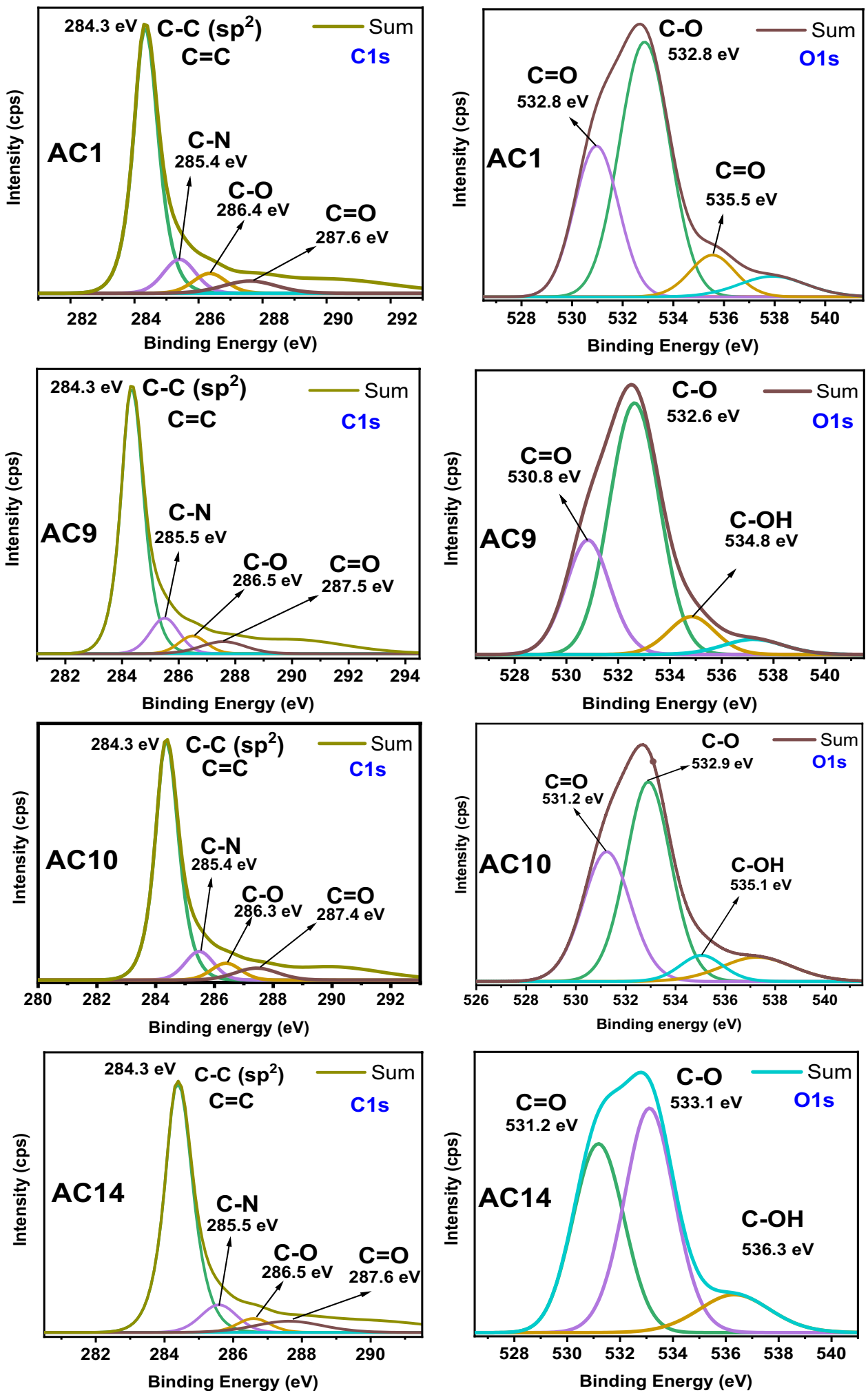

$\mathrm{m}^{2} \mathrm{~g}^{-1}$ (AC6) and $1374 \mathrm{~m}^{2} \mathrm{~g}^{-1}$ (AC14). On the other hand, $\mathrm{AC} 1, \mathrm{AC} 2, \mathrm{AC} 10$, and $\mathrm{AC} 12$ presented $\mathrm{I}_{\mathrm{D}} / \mathrm{I}_{\mathrm{G}}$ values higher than 1.00. AC1, AC2, and AC10 samples were pyrolysed at $900{ }^{\circ} \mathrm{C}$ while $\mathrm{AC} 12$ at $800{ }^{\circ} \mathrm{C}$.

\subsubsection{Hydrophobic-hydrophilic analysis (HI)}

The surface characteristics of the prepared ACs were evaluated by solvent vapours of different polarities using 


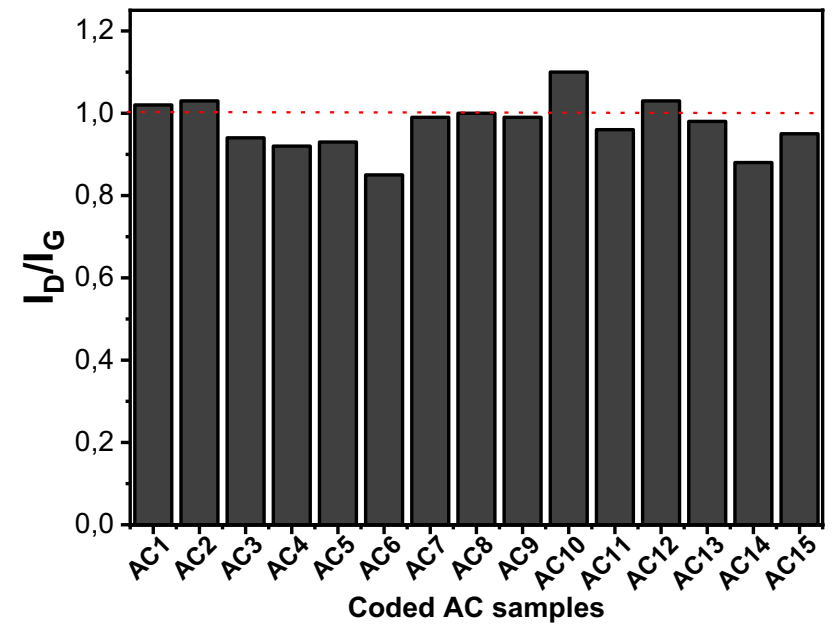

Fig. 5 Ratio of $\mathrm{I}_{\mathrm{D}} / \mathrm{I}_{\mathrm{G}}$ bands of the ACs

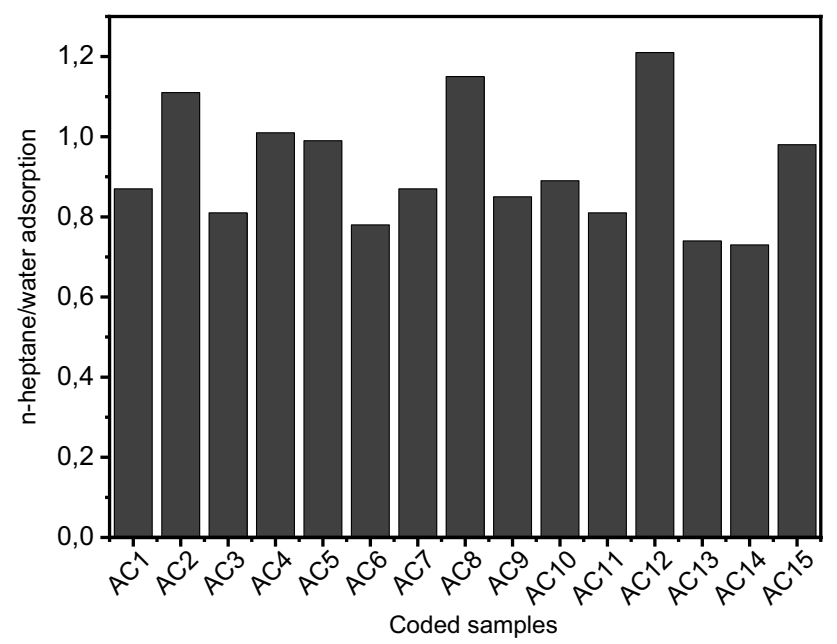

Fig. 6 Ratio of $n$-heptane and water adsorption values

n-heptane (less polar) and water (more polar) [18, 56, 57]. The hydrophobic-hydrophilic ratio is an important parameter to estimate the tendency of the material to adsorb compounds that are organic or water-based [56]. Figure 6 displays the calculated mass ratio of $n$-heptane to water uptake by all ACs. It is observed that all the AC surfaces are predominantly hydrophilic (see Fig. 6) since HI values are lower than 1.0. Hydrophilic groups on AC surfaces are related to $\mathrm{H}$-bonding and oxygen groups (already shown in Fig. 4) known to be present on biomass AC surfaces [18].

However, AC2, AC8, and AC12 presented HI values above 1.0, which means they have a hydrophobic behaviour. Interestingly, these three samples were made with a $\mathrm{ZnCl}_{2}$ :bark ratio of 2 and at higher temperatures (800 and $900{ }^{\circ} \mathrm{C}$ ); it seems that a high $\mathrm{ZnCl}_{2}$ concentration and high temperature lead to more hydrophobic surfaces. Leite et al. [18] prepared AC from avocado seed biomass and stated that an increase in pyrolysis temperature increased the $\mathrm{HI}$ values of the ACs. However, the hydrophobic/hydrophilic behaviour of ACs is not only influenced by the experimental pyrolysis condition and activation method. It also depends on the number of functional groups and types present on the AC's surface, the AC's aromatisation rate, and the chemical nature of the biomass precursor [35, 49, 57].

\subsubsection{Surface morphology (SEM analysis)}

SEM was employed to examine the effects of pyrolysis and activation conditions on the surface morphology characteristics of the AC samples. All SEM micrographs (Fig. 7) show rugosity, an irregular structure, holes, and cavities to a lesser or greater extent that agrees with the $\mathrm{S}_{\mathrm{BET}}$ and pore structure analyses. The SEM pictures reveal differences that indicate that the pyrolysis conditions and the ratio of $\mathrm{ZnCl}_{2}$ did influence the surface characteristics of the ACs.

Macropores are present in all samples. Macropores are very important if the AC is used as an adsorbent to remove water pollutants or electrodes in energy storage systems. They serve as vectors for the solution passage through the pores until it attains the micropores and mesopores. Depending on the preparation conditions, the AC external surfaces exhibited macropores of different sizes and shapes, reflecting their $\mathrm{S}_{\mathrm{BET}}, \mathrm{S}_{\mathrm{MICRO}}$, and $\mathrm{S}_{\mathrm{MESO}}$ values.

The ACs were found to be very porous regardless of the preparation condition. During the pyrolysis, it seems that the cavities and holes on the AC's surfaces resulted from the $\mathrm{ZnCl}_{2}$ state transformation-its low melting point at $290{ }^{\circ} \mathrm{C}$ and the boiling point at $732{ }^{\circ} \mathrm{C}$ are fused into the biomass matrix, thereby creating a denser structure and well-developed pore network $[5,6,11,18]$.

\subsubsection{Water vapour sorption}

Water vapour sorption isotherms for the $\mathrm{AC} 1, \mathrm{AC} 4, \mathrm{AC} 9$, $\mathrm{AC} 13, \mathrm{AC} 14$, and $\mathrm{AC} 15$ are shown in Fig. 8. According to the IUPAC classification [58], all isotherms are very close to type $\mathrm{V}$, characterised by little water uptake at low relative pressures and the presence of a hysteresis loop over a big part of the pressure range. Although the isotherms exhibited similar types and shapes, the hysteresis forms differ, indicating that the pyrolysis conditions influence the AC characteristics as previously discussed in the manuscript.

The $\mathrm{H}_{2} \mathrm{O}$ isotherms were not influenced by the AC's textural properties, such as $\mathrm{S}_{\mathrm{BET}}$, because the $\mathrm{AC}$ with the highest $\mathrm{S}_{\mathrm{BET}}$ presented one of the lowest $\mathrm{H}_{2} \mathrm{O}$ uptake values. Hence, the AC water vapour sorption may, contrary to the $\mathrm{N}_{2}$ adsorption, be very dependent on the surface chemistry, such as the presence of functional groups on the AC surface.

Water adsorption isotherms for most porous carbons exhibit a hysteresis loop. The size and shape of the loop 


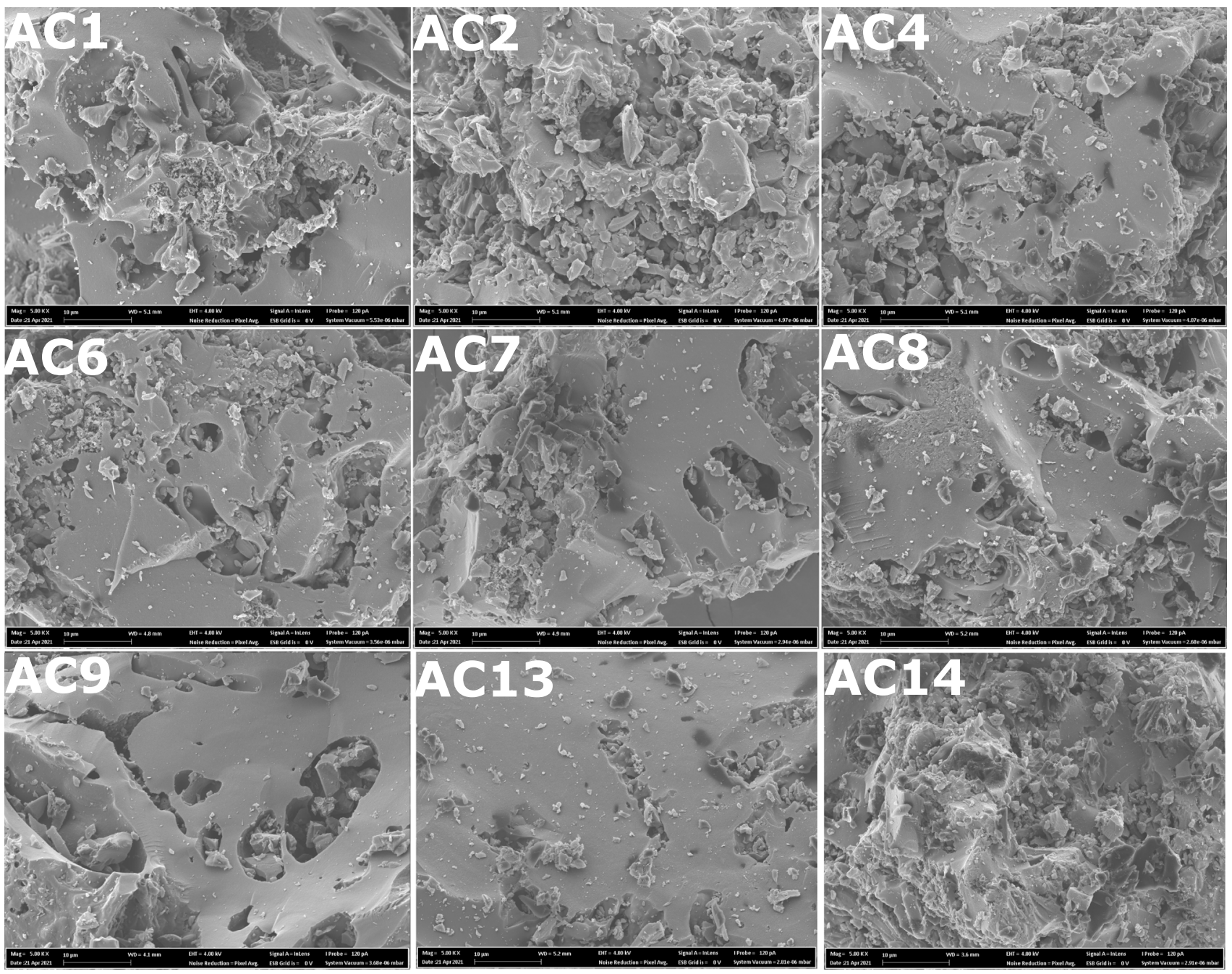

Fig. 7 SEM images of $\mathrm{AC}$ samples $\mathrm{AC} 1, \mathrm{AC} 2, \mathrm{AC} 4, \mathrm{AC} 6, \mathrm{AC} 7, \mathrm{AC} 8, \mathrm{AC} 9, \mathrm{AC} 13$, and $\mathrm{AC} 14$. All at $5 \mathrm{~K}$ of magnification

varied between ACs with different pore sizes and pore structures. From the isotherms displayed in Fig. 8, it is possible to see that AC8 - the most microporous sample (94.6\%) exhibited the longest and widest hysteresis. Gallego-Gomez reported that the completion of the micropore filling delays the onset of multilayer adsorption, leading to hysteresis at high relative pressure [59].

\subsubsection{DFC adsorption}

In this work, Norway spruce bark activated carbons were tested to remove DCF from aqueous solutions to evaluate their suitability for the adsorption process (see Fig. 9). The ACs displayed very high adsorption capacity values (272-417.4 $\mathrm{mg} \mathrm{g}^{-1}$ ). Their physicochemical properties can explain the high efficiency of the $\mathrm{AC}$ in removing DFC. All ACs presented very high $\mathrm{S}_{\mathrm{BET}}$ and well-developed pore structure in the range of mesoporosity with few samples mainly composed of micropores. Both micro- and mesoporous ACs are highly efficient to adsorb DFC molecules with a small molecule size $(1.015 \mathrm{~nm})$ [62]. The DCF molecule can easily be accommodated in pores bigger than its size, which is the case of micropores up to $2.0 \mathrm{~nm}$ and mesopores up to $50.0 \mathrm{~nm}$.

The results exhibited in Fig. 9 indicate that the prepared ACs could be successfully employed to remove DFC and organic emerging compounds from aqueous solutions.

Comparing our results with the literature data, the adsorption capacity $(q)$ of the best performing AC (AC14) is comparable and even higher to the adsorption capacities of many different adsorbents reported in the literature (see Table 6). Compared to ACs produced in other works, the high diclofenac adsorption capacity efficiency can be attributed to the small particle size and high developed porosity and the functional groups present on the surface of the ACs. 
Fig. 8 Water vapour adsorption isotherms at $30{ }^{\circ} \mathrm{C}$
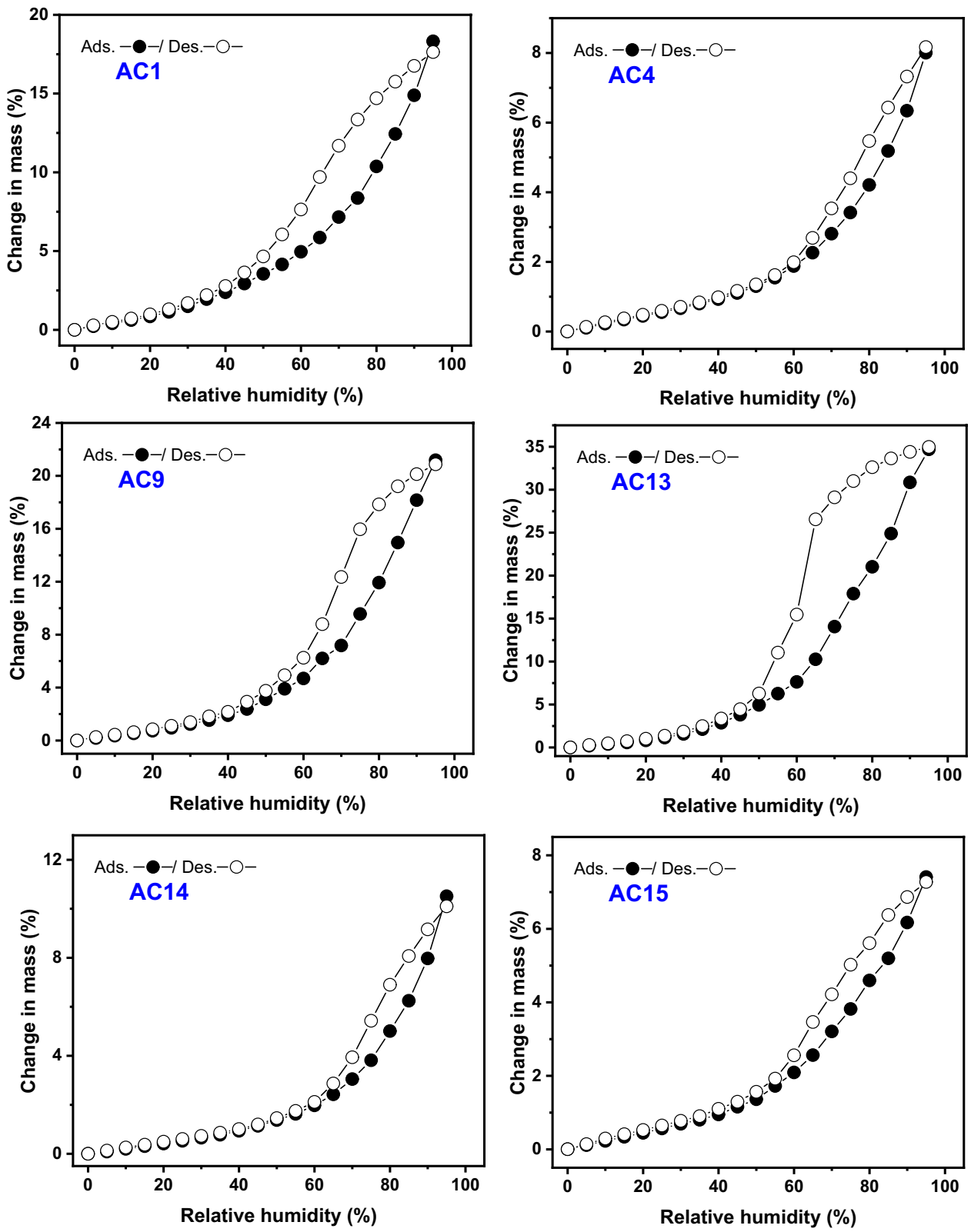

Table 6 shows that Norway spruce bark AC (AC14) had the second-highest adsorption capacity (417.4 $\mathrm{mg} \mathrm{g}^{-1}$ ) among all presented adsorbents. The highest $q$ value (444.44 $\mathrm{mg} \mathrm{g}^{-1}$ ) was reached by polyethyleneimine-functionalised sodium alginate/cellulose nanocrystal/polyvinyl alcohol core-shell microspheres (PVA/SA/CNC)@ PEI). Although PVA/SA/CNC)@PEI presented a higher $q$ value than AC14, its production cost is incredibly much higher when compared to that of AC14. Consequently, if the production cost is added to the desirable properties, $\mathrm{ZnCl}_{2}$-activated Norway spruce AC could be classified as an excellent adsorbent to remove DFC from aqueous solutions.

\section{Conclusion}

Norway spruce bark can be a very suitable feedstock for the production of activated carbons with well-developed porosity. Response surface methodology based on Box-Behnken design was confirmed to be effective in optimising activated carbons' preparation. Three responses were studied: $\mathrm{S}_{\mathrm{BET}}$, mesoporosity ( $\mathrm{S}_{\mathrm{MESO}}$ ), and microporosity $\left(\mathrm{S}_{\mathrm{MICRO}}\right)$. The maximum values for the responses were obtained at the following conditions: $\mathrm{S}_{\mathrm{BET}}: 700{ }^{\circ} \mathrm{C}$, $1 \mathrm{~h}$, and 1.5:1 (sample AC14), $\mathrm{S}_{\mathrm{MESO}}: 700{ }^{\circ} \mathrm{C}, 2 \mathrm{~h}$, and 2:1, and $\mathrm{S}_{\mathrm{MICRO}}: 800{ }^{\circ} \mathrm{C}, 3 \mathrm{~h}$, and $2: 1 \mathrm{ZnCl}_{2}$ :bark ratio. 


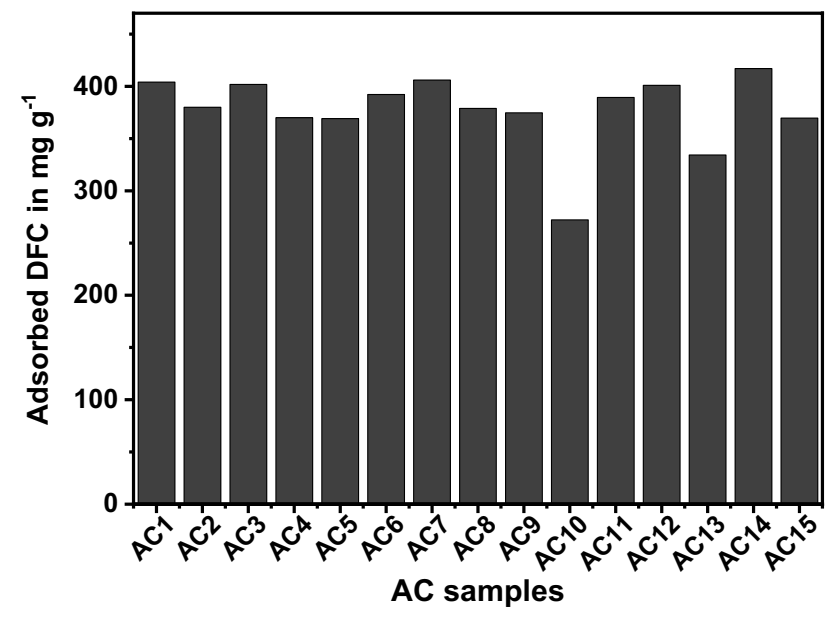

Fig. 9 DFC adsorption capacity on spruce bark activated carbons

Table 6 Comparison of the adsorption capacities for diclofenac using different adsorbents

\begin{tabular}{llrl}
\hline Adsorbents & $q\left(\mathrm{mg} \mathrm{g}^{-1}\right)$ & $\mathrm{pH}$ & Ref \\
\hline $\begin{array}{l}\text { Sewage sludge-polysiloxanes com- } \\
\text { posite }\end{array}$ & 26.12 & 7.0 & {$[57]$} \\
Reduced graphene oxide & & & \\
Commercial AC & 59.67 & 10.0 & {$[60]$} \\
Carbon nanotubes/alumina hybrid & 33 & 5.5 & {$[61]$} \\
Chloride-modified zeolite & 31.35 & 7.4 & {$[63]$} \\
Activated carbon from cocoa shell & 63.47 & 7.0 & {$[64]$} \\
Graphene oxide nanosheets & 128.75 & 6.2 & {$[65]$} \\
Carbon xerogel & 80.0 & 7.0 & {$[66]$} \\
AC from olive stones & 11.01 & 4.2 & {$[67]$} \\
AC derived from pine tree & 54.67 & 7.0 & {$[68]$} \\
Sewage sludge activated carbon & 157.4 & 7.0 & {$[69]$} \\
PVA/SA/CNC) @ PEI & 444.44 & 5.0 & {$[70]$} \\
Norway spruce bark AC (AC14) & 417.4 & 6.0 & This work \\
\end{tabular}

The highest $\mathrm{S}_{\mathrm{BET}}$, $\mathrm{S}_{\mathrm{MESO}}$, and $\mathrm{S}_{\mathrm{MICRO}}$ were 1374,1311 , and $1117 \mathrm{~m}^{2} \mathrm{~g}^{-1}$, respectively. The $\mathrm{ZnCl}_{2}$ ratio and pyrolysis temperature were the most critical factors for the $\mathrm{S}_{\mathrm{BET}}$, while the interaction between temperature and $\mathrm{ZnCl}_{2}$ ratio was the most significant factor for $\mathrm{S}_{\mathrm{MESO}}$. For the $\mathrm{S}_{\mathrm{MICRO}}$, holding time was the most important factor.

The spruce bark AC showed predominant mesoporous structures and relatively high yield compared to the literature. Based on $\mathrm{I}_{\mathrm{D}} / \mathrm{I}_{\mathrm{G}}$ values, the AC samples with the highest $S_{\text {BET }}$ values presented much more disordered structures. The water vapour results suggested that the $\mathrm{H}_{2} \mathrm{O}$ adsorption was not controlled by the textural properties of AC but rather by their chemical properties and the availability of functional sites. The DFC adsorption data showed that the AC displayed very high adsorption capacity values
(272-417.4 $\mathrm{mg} \mathrm{g}^{-1}$ ), and the sample with the highest $\mathrm{S}_{\mathrm{BET}}$ (AC14) also exhibited the highest $q$ value $\left(417.4 \mathrm{mg} \mathrm{g}^{-1}\right.$ ) for DFC removal.

The large surface area, interesting chemical structure, and high DFC adsorption capacity of the ACs in this study show a great potential of Norway spruce bark residues as a precursor material for the production of $\mathrm{AC}$ with good adsorption properties.

Funding Open access funding provided by Swedish University of Agricultural Sciences. This research was funded by the Treesearch Postdoctoral program, Bio4Energy—a Strategic Research Environment appointed by the Swedish government, and the Swedish University of Agricultural Sciences. Ms. Mathieu thanks ERASMUS for the financial support.

Open Access This article is licensed under a Creative Commons Attribution 4.0 International License, which permits use, sharing, adaptation, distribution and reproduction in any medium or format, as long as you give appropriate credit to the original author(s) and the source, provide a link to the Creative Commons licence, and indicate if changes were made. The images or other third party material in this article are included in the article's Creative Commons licence, unless indicated otherwise in a credit line to the material. If material is not included in the article's Creative Commons licence and your intended use is not permitted by statutory regulation or exceeds the permitted use, you will need to obtain permission directly from the copyright holder. To view a copy of this licence, visit http://creativecommons.org/licenses/by/4.0/.

\section{References}

1. Marsh H, Rodríguez-Reinoso F (2016) Activated carbon. Elsevier Science

2. Tan XF, Liu SB, Liu YG, Gu YI, Zeng GM, Hu XJ, Wang X, Liu SH, Jiang LH (2017) Biochar as potential sustainable precursors for activated carbon production: multiple applications in environmental protection and energy storage. Biores Technol 227:359-372

3. Wang J, Kong H, Zhang J, Hao Y, Shao Z, Ciucci F (2021) Carbon-based electrocatalysts for sustainable energy applications, Progress in Materials Science 116: 100717

4. Hassan MF, Sabri MA, Fazal H, Hafeez A, Shezad N, Hussain M (2020) Recent trends in activated carbon fibers production from various precursors and applications-a comparative review. J Analytical Appl Pyrol 145:104715

5. Thue PS, Umpierres CS, Lima EC, Lima DR, Machado FM, dos Reis GS, da Silva RS, Pavan FA, Tran HN (2020) Single-step pyrolysis for producing magnetic activated carbon from tucumã (Astrocaryum aculeatum) seed and nickel(II) chloride and zinc(II) chloride. Application for removal of Nicotinamide and Propanolol. J Hazard Mater 398: 122903

6. Umpierres CS, Thue PS, dos Reis GS, de Brum IAS, Lima EC, de Alencar WA, Dias SLP, Dotto GL (2018) Microwave activated carbons from tucumã (Astrocaryum aculeatum) waste for efficient removal of 2-nitrophenol from aqueous solutions. Environ Technol 39:1173-1187

7. Lima DR, Hosseini-Bandegharaei A, Thue PS, Lima EC, de Albuquerque YRT, dos Reis GS, Umpierres CS, Dias SLP, Tran HN (2019) Efficient acetaminophen removal from water and hospital 
effluents treatment by activated carbons derived from Brazil nutshells. Colloid Surf A 583:123966

8. Chen R, Li L, Liu Z, Lu M, Wang C, Li H, Ma W, Wang S (2017) Preparation and characterization of activated carbons from tobacco stem by chemical activation. J Air Waste Management Ass 67(6):713-724

9. dos Reis GS, Larsson SH, Oliveira HP, Thyrel M, Lima EC (2020) Sustainable biomass activated carbons as electrodes for battery and supercapacitors - a mini-review. Nanomaterials 10:1398

10. dos Reis GS, Oliveira HP, Larsson SH, Thyrel M, Lima EC (2021) A short review on the electrochemical performance of hierarchical and nitrogen-doped activated biocarbon-based electrodes for supercapacitors. Nanomaterials 11:424

11. dos Reis GS, Wilhelm M, Silva TCA, Rezwan K, Sampaio CH, Lima EC, Souza SMAGU (2016) The use of design of experiments for the evaluation of the production of surface-rich activated carbon from sewage sludge via microwave and conventional pyrolysis. Appl Therm Eng 93:590

12. Varila T, Brännström $H$, Kilpeläinen $P$, Hellström J, Romar H, Nurmi J, Lassi U (2020) From Norway spruce bark to carbon foams: characterization and applications. BioRes 15:3651-3666

13. El Maguana Y, Elhadiri N, Bouchdoug M, Benchana M (2018) Study of the influence of some factors on the preparation of activated carbon from walnut cake using the fractional factorial design. J Environ Chem Eng 6:1093-1099

14. Brazil TR, Gonçalves M, Junior MSO, Rezende MC (2020) A statistical approach to optimise the activated carbon production from Kraft lignin based on conventional and microwave processes. Micro Meso Mat 308:110485

15. Box GEP, Hunter WG, Hunter JS (1978) Statistics for experimenters: an introduction to design, data analysis and model building, 2nd edn. John Wiley \& Sons, New York

16. Gratuito MKB, Panyathanmaporn T, Chumnanklang RA, Sirinuntawittaya N, Dutta A (2008) Production of activated carbon from coconut shell: optimisation using response surface methodology. Bioresour Technol 99:4887-4895

17. González PG, Hernández-Quiroz T, García-González L (2014) The use of experimental design and response surface methodologies for the synthesis of chemically activated carbons produced from bamboo, Fuel Process. Technol 127:133-139

18. Leite AB, Saucier C, Lima EC, dos Reis GS, Umpierres CS, Mello BL, Shimardi M, Dias SL, Sampaio CH (2018) Activated carbons from avocado seed: optimisation and application for removal of several emerging organic compounds. Environ Sci Pollut Res 25:7647-7661

19. Duan X, Peng J, Srinivasakannan C, Zhang L, Xia H, Yang K (2011) Process optimisation for the preparation of activated carbon from Jatropha Hull using response surface methodology. Ener Source 33:2005-2017

20. Zhanyong L, Wang K, Song J, Xu Q, Kobayashi N (2014) Preparation of activated carbons from polycarbonate with chemical activation using response surface methodology. J Mat Cycles Waste Manage 16:359-366

21. Karacan F, Ozden U, Karacan S (2007) Optimisation of manufacturing conditions for activated carbon from Turkish lignite by chemical activation using response surface methodology. Appl Thermal Eng 27:1212-1218

22. Ayyalusamy S, Mishra S (2018) Optimisation of preparation conditions for activated carbons from polyethylene terephthalate using response surface methodology. Brazilian J Chem Eng 35(3):1105-1116

23. Jansen S, Konrad H, Geburek T (2017) The extent of historic translocation of Norway spruce forest reproductive material in Europe. Ann For Sci 74:56

24. Ghitescu RE, Volf I, Carausu C, Bühlmann AM, Gilca IA, Popa VI (2015) Optimisation of ultrasound-assisted extraction of polyphenols from spruce wood bark. Ultrason Sonochem 22:535-541

25. Krogell J, Holmbom B, Pranovich A, Hemming J, Willför S (2012) Extraction and chemical characterisation of Norway spruce inner and outer bark. Nord Pulp Pap Res J 27:6-17

26. Siipola V, Pflugmacher S, Romar H, Wendling L, Koukkari P (2020) Low-cost biochar adsorbents for water purification including microplastics removal. Appl Sci 10:788

27. Kumar A, Prasad B, Mishra IM (2008) Optimisation of process parameters for acrylonitrile removal by a low-cost adsorbent using Box-Behnken design. J Hazard Mat 150:174-182

28. Ferreira SLC, Bruns RE, Ferreira HS, Matos GD, David JM, Brandao GS, da Silva EGP, Portugal LA, dos Reis PS, Souza AS, dos Santos WNL (2007) Box-Behnken design: an alternative for the optimization of analytical methods. Analyt Chim Acta 597:179-186

29. Bergna D, Varila T, Romar H, Lassi U (2018), C 4: 41

30. Sulaiman NS, Hashim R, Amini MHM, Danish M, Sulaiman O (2018) Optimisation of activated carbon preparation from cassava stem using response surface methodology on surface area and yield. J Cleaner Prod 198:1422-1430

31. Yuan Z, Xu Z, Zhang D, Chen W, Zhang T, Huang Y, Gu L, Deng H, Tian D (2018) Box-Behnken design approach towards optimisation of activated carbon synthesised by co-pyrolysis of waste polyester textiles and $\mathrm{MgCl}_{2}$. Appl Surf Sci 427:340-348

32. Danish M, Hashim R, Ibrahim MNM, Sulaiman O (2014) Optimisation study for preparation of activated carbon from Acacia mangium wood using phosphoric acid. Wood Sci Technol 48:1069-1083

33. Bouchelta C, Medjram MS, Zoubida M, Chekkat FA, Ramdane N, Bellat JP (2012) Effects of pyrolysis conditions on the porous structure development of date pits activated carbon. J Analytical Appl Pyrol 94:215-222

34. E.M. Mistar, T. Alfatah, M.D. Supardan, Synthesis and characterisation of activated carbon from Bambusa vulgaris Striata using two-step KOH activation, j mat technol . 202 0;9(3):6278-6286

35. Galiatsatou P, Metaxas M, Kasselouri-Rigopoulou V (2001) Mesoporous activated carbon from agricultural byproducts. Mikrochim Acta 136:147-152

36. Morali U, Demiral H, Sensoz S (2018) Optimisation of activated carbon production from sunflower seed extracted meal: Taguchi design of experiment approach and analysis of variance. J Cleaner Prod 189:602-611

37. Fröhlich AC, dos Reis GS, Pavan PA, Lima EC, Foletto EL, Dotto GL (2018) Improvement of activated carbon characteristics by sonication and its application for pharmaceutical contaminant adsorption. Environ Sci Pollution Res 25:24713-24725

38. dos Reis GS, Adebayo MA, Lima EC, Sampaio CH, Prola LDT (2016) Activated carbon from sewage sludge for preconcentration of copper. Anal Lett 49:541-555

39. Thue PS, Lima EC, Sieliechi JM, Saucier C, Dias SLP, Vaghetti JCP, Rodembusch FS, Pavan FA (2017) Effects of first-row transition metals and impregnation ratios on the physicochemical properties of microwave-assisted activated carbons from wood biomass. J Colloid Interf Sci 486:163-175

40. Leite AJB, Sophia AC, Thue PS, dos Reis GS, Dias SLP, Lima EC, Vaghetti JCP, Pavan FA, de Alencar WS (2017) Activated carbon from avocado seeds for the removal of phenolic compounds from aqueous solutions. Desalin Water Treat 71:168-181

41. Kumar A, Jena HM (2016) Preparation and characterisation of high surface area activated carbon from Fox nut (Euryale ferox) shell by chemical activation with $\mathrm{H}_{3} \mathrm{PO}_{4}$. Results in Physics 6:651-658

42. Abioye AM, Abdulkadir LN, Sintali IS, Bawa MA, An FN (2020) Temperature controlled microwave-induced $\mathrm{CO} 2$ activated 
carbon: optimisation using Box-Behnken design. Adv Eng Res 198:129-135

43. Lopes GKP, Zanella HG, Spessato L, Ronix A, Viero P, Fonseca JM, Yokoyama JTC, Cazetta AL, Almeida VC (2021) Steamactivated carbon from malt bagasse: optimisation of preparation conditions and adsorption studies of sunset yellow food dye. Arabian J Chem 14: 103001

44. Almahbashi NMY, Kutty SMN, Ayoub M, Noor A, Salihi IU, AlNini A, Jagaba AH, Aldhawi BNS, Ghaleb AAS Optimisation of preparation conditions of sewage sludge based activated carbon, https://doi.org/10.1016/j.asej.2020.07.026

45. Bacaoui A, Yaacoubi A, Dahbi A, Bennouna C, Luu PT, Maldonado-Hodar FJ, Rivera-Utrilla J, Moreno-Castilla C (2001) Optimisation of conditions for the preparation of activated carbons from olive-waste cakes. Carbon 39:425-432

46. Anuwar NA, Khamaruddin PFM (2020) Optimisation of chemical activation conditions for activated carbon from coconut shell using response surface methodology (RSM) and its ability to adsorb $\mathrm{CO}_{2}$, Advances in Engineering Research, Vol. 200, Proceedings of the Third International Conference on Separation Technology 2020 (ICoST 2020)

47. Correa CR, Otto T, Kruse A (2017) Influence of the biomass components on the pore formation of activated carbon. Biomass Bioenergy 97:53-64

48. Duan XH, Srinivasakannan C, Yang KB, Peng JH, Zhang LB (2012) Effects of heating method and activating agent on the porous structure of activated carbons from coconut shells. Waste Biomass Valor 3:131-139

49. Luo QP, Huang L, Gao X, Cheng Y, Yao B, Hu Z, Wan J, Xiao X, Zhou J (2015) Activated carbon derived from Melaleuca barks for outstanding high-rate supercapacitors, Nanotechnology. 26: 304004

50. Ahmed W, Mehmood S, Qaswar M, Ali S, Khan ZH, Ying H, Chen DY, Núnez-Delgado A (2015) Oxidised biochar obtained from rice straw as adsorbent to remove uranium (VI) from aqueous solutions. J Environ Chem Eng 9: 105104

51. T-t. Qin, Z-q. Shi, M-w. Li, C-y. Wang, Effect of reduction heat treatment in $\mathrm{H} 2$ atmosphere on structure and electrochemical properties of activated carbon, J Solid State Electrochem (2015) 19:1437-1446

52. Ranguin R, Ncibi MC, Cesaire T, Lavoie S, Jean-Marius C, Grutzmacher H, Gaspard S (2020) Development and characterisation of a nanostructured hybrid material with vitamin B12 and bagassederived activated carbon for anaerobic chlordecone (Kepone) removal. Environ Sci Pollution Res 27:41122-41131

53. Pawlyta M, Rouzaud J, Duber S (2015) Raman microspectroscopy characterisation of carbon blacks: spectral analysis and structural information. Carbon 84:479-490

54. Piergrossi V, Fasolato C, Capitani F, Monteleone G, Postorino G, Gislon P (2019) Application of Raman spectroscopy in chemical investigation of impregnated activated carbon spent in hydrogen sulfide removal process. Int J Environ Sci Technol 16:1227-1238

55. Sheka EF, Golubev YA, Popova NA (2020) Graphene domain signature of Raman spectra of sp2 amorphous carbons. Nanomaterials 10:2021

56. dos Reis GS, Lima EC, Sampaio CH, Rodembusch FS, Petter CO, Cazacliu BG, Dotto GL, Hidalgo GEN (2018) Novel kaolin/ polysiloxane based organic-inorganic hybrid materials: sol-gel synthesis, characterisation, and photocatalytic properties. J Solid State Chem 260:106-116
57. dos Reis GS, Sampaio CH, Lima EC, Wilhelm M (2016) Preparation of novel adsorbents based on combinations of polysiloxanes and sewage sludge to remove pharmaceuticals from aqueous solutions. Colloids Surf A 497:304-315

58. Thommes M, Kaneko K, Neimark AV, Olivier JP, RodriguezReinoso F, Rouquerol J (2015) Physisorption of gases, with special reference to the evaluation of surface area and pore size distribution (IUPAC technical report). Pure Appl Chem 87(9-10):1051-1069

59. Gallego-Gomez F, Farrando-Perez J, Lopez C, Silvestre-Albero J (2020) Micropore filling and multilayer formation in Stöber spheres upon water adsorption. J Phys Chem C 124:20922-20930

60. Jauris IM, Matos CF, Saucier C, Lima EC, Zarbin AJG, Fagan SB, Machado FM, Zanella I (2016) Adsorption of sodium diclofenac on graphene: a combined experimental and theoretical study. Phys Chem Chem Phys 18:1526-1536

61. Antunes M, Esteves VI, Guegan R, Crespo JS, Fernandes AN, Giovanela M (2012) Chem Eng J 192:114-121

62. Wei H, Deng S, Huang Q, Nie Y, Wang B, Huang J, Yu G (2013) Regenerable granular carbon nanotubes/alumina hybrid adsorbents for diclofenac sodium and carbamazepine removal from aqueous solution. Water Res 47:4139-4147

63. Krajisnik D, Dakovic A, Milojevic M, Malenovic A, Kragovic M, Bogdanovic MD, Dondur V, Milic J (2011) Properties of diclofenac sodium sorption onto natural zeolite modified with cetylpyridinium chloride. Colloids Surf., B, 2011, 83, 165-172.

64. Saucier C, Adebayo MA, Lima EC, Cataluna R, Thue PS, Prola LDT, Puchana-Rosero MJ, Machado FM, Pavan F, Dotto GL (2015) Microwave-assisted activated carbon from cocoa shell as adsorbent for removal of sodium diclofenac and nimesulide from aqueous effluents. J Hazard Mater 289:18-27

65. Guerra ACS, de Andrade MB, dos Santos TRT, Bergamasco R (2019) Adsorption of sodium diclofenac in aqueous medium using graphene oxide nanosheets, Environ. Technol. DOI: https://doi. org/10.1080/09593330.2019.1707882

66. Álvarez S, Ribeiro RS, Gomes HT, Sotelo JL, García J (2015) Synthesis of carbon xerogels and their application in adsorption studies of caffeine and diclofenac as emerging contaminants. chem Eng Res design 95: 229-238

67. Naghipour D, Hoseinzadeh L, Taghavi K (2028) Characterisation, kinetic, thermodynamic and isotherm data for diclofenac removal from aqueous solution by activated carbon derived from pine tree. Data Brief 18:1082-1087

68. Larous S, Meniai A-H (2016) Adsorption of diclofenac from aqueous solution using activated carbon prepared from olive stones. Int J Hydrogen Energy 41:10380-10390

69. dos Reis GS, Mahbub MKB, Wilhelm M, Sampaio CH, Lima EC, Saucier C, Dias SLP (2016) Activated carbon from sewage sludge for removal of sodium diclofenac and nimesulide from aqueous solutions. Korean J Chem Eng 33:3149-3161

70. Fan L, Lu Y, Yang L-Y, Huang F, Ouyang X-K (2019) Fabrication of polyethylenimine-functionalized sodium alginate/cellulose nanocrystal/polyvinyl alcohol core-shell microspheres ((PVA/SA/ CNC)@ PEI) for diclofenac sodium adsorption. J Colloid Interface Sci 554:48-58

Publisher's note Springer Nature remains neutral with regard to jurisdictional claims in published maps and institutional affiliations. 